Hydrol. Earth Syst. Sci., 14, 2039-2056, 2010

www.hydrol-earth-syst-sci.net/14/2039/2010/

doi:10.5194/hess-14-2039-2010

(C) Author(s) 2010. CC Attribution 3.0 License.

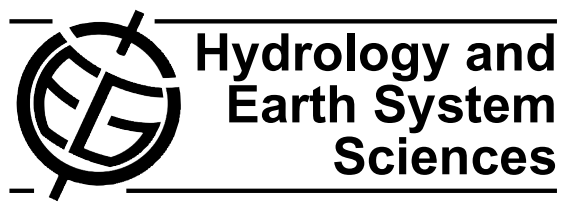

\title{
Potential groundwater contribution to Amazon evapotranspiration
}

\author{
Y. Fan ${ }^{1}$ and G. Miguez-Macho ${ }^{2}$ \\ ${ }^{1}$ Department of Earth \& Planetary Sciences, Rutgers University, New Brunswick, NJ 08854, USA \\ ${ }^{2}$ Non-linear Physics Group, Universidade de Santiago de Compostela, Galicia, Spain
}

Received: 10 July 2010 - Published in Hydrol. Earth Syst. Sci. Discuss.: 30 July 2010

Revised: 7 October 2010 - Accepted: 13 October 2010 - Published: 25 October 2010

\begin{abstract}
Climate and land ecosystem models simulate a dry-season vegetation stress in the Amazon forest, but observations do not support these results, indicating adequate water supply. Proposed mechanisms include larger soil water store and deeper roots in nature and the ability of roots to move water up and down (hydraulic redistribution), both absent in the models. Here we provide a first-order assessment of the potential importance of the upward soil water flux from the groundwater driven by capillarity. We present a map of equilibrium water table depth from available observations and a groundwater model simulation constrained by these observations. We then present a map of maximum capillary flux these water table depths, combined with the fine-textured soils in the Amazon, can potentially support. The maps show that the water table beneath the Amazon can be shallow in lowlands and river valleys ( $<5 \mathrm{~m}$ in $36 \%$ and $<10 \mathrm{~m}$ in $60 \%$ of Amazonia). These water table depths can potentially accommodate a maximum capillary flux of $2.1 \mathrm{~mm} \mathrm{day}^{-1}$ to the land surface averaged over Amazonia, but varies from 0.6 to $3.7 \mathrm{~mm}_{\text {day }}{ }^{-1}$ across nine study sites.

We note that the results presented here are based on limited observations and simple equilibrium model calculations, and as such, have important limitations and must be interpreted accordingly. The potential capillary fluxes are not indicative of their contribution to the actual evapotranspiration, and they are only an assessment of the possible rate at which this flux can occur, to illustrate the power of soil capillary force acting on a shallow water table in fine textured soils. They may over-estimate the actual flux where the surface soils remain moist. Their contribution to the actual evapotranspiration can only be assessed through fully coupled model simulation of the dynamic feedbacks between soil water and groundwater with sub-daily climate forcing.
\end{abstract}

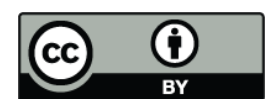

Correspondence to: Y. Fan

(yingfan@ rci.rutgers.edu)
The equilibrium water table obtained here serves as the initial state for the dynamic simulation, and together with the equilibrium potential capillary flux, will serve as a baseline to evaluate the diurnal, event, seasonal and inter-annual dynamics.

\section{Introduction}

The Amazon rainforest is the planet's largest and biologically richest ecosystem, and the threat of climate change and deforestation requires an understanding of its responses and feedbacks to its environment. One standing question is how well the forest fares in the dry season under the climate today, which is pertinent to how well it will fare under the projected future climate with a longer dry-season. Although annual rainfall is abundant, a large part of the Amazon experiences a multi-month dry season in the Austral winter. Soil water deficit and partial shut-down of photosynthesis are indeed simulated in state-of-art climate and ecosystem models (Kleidon and Heimann, 2000; Werth and Avissar, 2004; Baker et al., 2008; da Rocha et al., 2009). However, a seminal paper over two decades ago (Shuttleworth, 1988) based on observational syntheses had shown that evapotranspiration (ET) in the dry season is no less than in the wet season. Subsequent flux-tower measurements at multiple sites and satellite images revealed the same (Saleska et al., 2003; Xiao et al., 2005; Huete et al., 2006; Ichii et al., 2007; Myneni et al., 2007; Juarez et al., 2007; Fisher et al., 2009), all suggesting that the Amazon forest as whole does well in the dry-season.

A considerable literature exists proposing different mechanisms to explain the observed absence of water stress. First, soil water store is far greater in nature then assumed in most land surface models; in nature, this storage is filled in the wet season and supports ET in the following dry season; in models, excess infiltration drains through the soil column

Published by Copernicus Publications on behalf of the European Geosciences Union. 
and is removed as river outflow, no longer available for plant use later. Second, tree roots extend deeper than model soilroot system and can access deep water (Nepstad et al., 1994; Kleidon and Heimann, 2000; Ichii et al., 2007; Harper et al., 2010). But global syntheses of observations suggest that $95 \%$ of root mass resides in the top $2 \mathrm{~m}$ of soil for all major biomes of the world (Schenck and Jackson, 2002), and tracer studies in the field found that the root system does not seem to take water beyond $2 \mathrm{~m}$ depth (Sternberg et al., 2002; Romero-Saltos et al., 2005). These observations suggest that the role of deeper roots is not entirely clear, and they seem to justify the common practice of including only the top $2 \mathrm{~m}$ soil in models. Third, the small fraction of deep roots, albeit insignificant in mass, can be efficient water conduits via hydraulic lift or redistribution (HR) (Dawson, 1993; Caldwell et al., 1998; Burgess et al., 1998; Oliveira et al., 2005; Lee et al, 2005; Amenu and Kumar, 2008); rooting depth can be tens of meters in plants relying on deep sources as in arid climate (Canadell et al., 1996). A modeling study (Lee et al., 2005) found that incorporating HR significantly reduced, although far from eliminated, the model ET bias (still 50\% less than observed). The modeling study by Baker at al. (2008) further shows that the combination of all above (deep soil, deep roots, and HR) performs better than any one alone. Fourth, upward soil water flux driven by capillary force in the dry season, from the deeper and wetter soil to the shallower and drier soil, may be an important mechanism (da Rocha et al., 2004; Romero-Saltos et al., 2005; Bruno et al., 2006). Finally, the groundwater may be a source where it is directly accessible by roots as suggested by field studies (Poels, 1987; Vourlitis et al., 2008). Diurnal variations in water table depth that coincide with the period of photosynthesis in a Suriname rainforest are direct indications of water table contribution to forest ET (Poels, 1987).

We have not found any systematic investigations of the influence of groundwater on land surface fluxes across the wide range of hydrologic-ecologic conditions found in the Amazon. Observations of water table depth were reported at very few sites in the Large Scale Biosphere-Atmosphere Experiment in Amazonia (LBA), an internationally-coordinated research initiative led by Brazilian scientists. Nor did we find Amazon-wide modeling studies that incorporate the water table in simulating Amazon land surface fluxes. The objective of this study is to make a preliminary assessment of the potential importance of the groundwater. First, we present water table observations compiled from multiple sources. Second, we synthesize the sparse observations using a simple 2dimensional groundwater flow model, to interpolate the observations and to elucidate process controls on water table depth from hillsope to continental scales. Third, we calculate the potential (maximum) capillarity-driven soil water fluxes from the modeled water table in the Amazon by solving the Richards Equation, and place them in the context of available ET estimates. Throughout the study, we attempt to keep the methodology as simple as possible.

\section{Water table observations}

The first issue to be examined is the depth of the water table. A deep water table will have little influence on rootzone soil moisture and surface fluxes, but a shallow water table (within or not far below rooting depth) will impede soil water drainage during rain periods and hence prolong the effect of rain, and moisten deep roots and shallow soil during dry periods via hydraulic redistribution and capillary flux.

We compiled observations of water table depth (WTD) at 34351 sites over the South American continent (Fig. 1) from government archives and published literature. We searched the government database of each country in S. America and each province except for Brazil and Chile which have a national database. Repeated emails were sent and phone calls were made where no data was found on the government website or the data is incomplete. Tens of published articles are also found which reported the water table depth. Data are mostly presented as plots or maps, from which we read the approximate values. More information on the compilation of these observations are provided in the Supplement.

The Brazilian Geological Survey (http://siagasweb.cprm. gov.br/layout/index.php, last accessed on 14 October 2010) is the single largest source (98\%) with 33570 wells in unconfined aquifers. Unfortunately they are concentrated in the developed eastern and southeastern Brazil and clustered over large metro regions, because these wells were drilled for groundwater exploitation, not for observation and research; groundwater is considered cleaner and has replaced surface water to be the major source for municipal supply. About $95 \%$ of the wells in the dataset report high pumping rates. In Amazonia, all metro regions are situated on principle aquifers and supplied by groundwater (see Fig. S1, Supplement). This introduces a low bias in the observations, an issue to be kept in mind when validating model simulations that cannot incorporate groundwater pumping. However, this is the best dataset available at this time, and it offers a lower bound to the natural water table depth.

In the Amazon, WTD varied from land surface to $159 \mathrm{~m}$ (distribution shown in Fig. 1 inset). Even with widespread pumping, the water table is relatively shallow: $34 \%$ of the sites with WTD $<5 \mathrm{~m}, 57 \%$ of the sites with WTD $<10 \mathrm{~m}$, and the peak of the histogram occurs at $2-4 \mathrm{~m}$. This suggests that a shallow WTD is widely observed. At least at these observation sites, it has the potential to influence the land surface.

However, these observations are far too sparse to resolve the spatial variations in water table at scales relevant to surface and groundwater convergence (hilltops to valleys) and to synthesize the patterns of climate and terrain control on groundwater regimes across the continent. There is a need to first, interpolate the observations to fill in the gaps, and second, to synthesize the observations within the framework of hydrologic processes, so that the hydrologic reasons of deep 


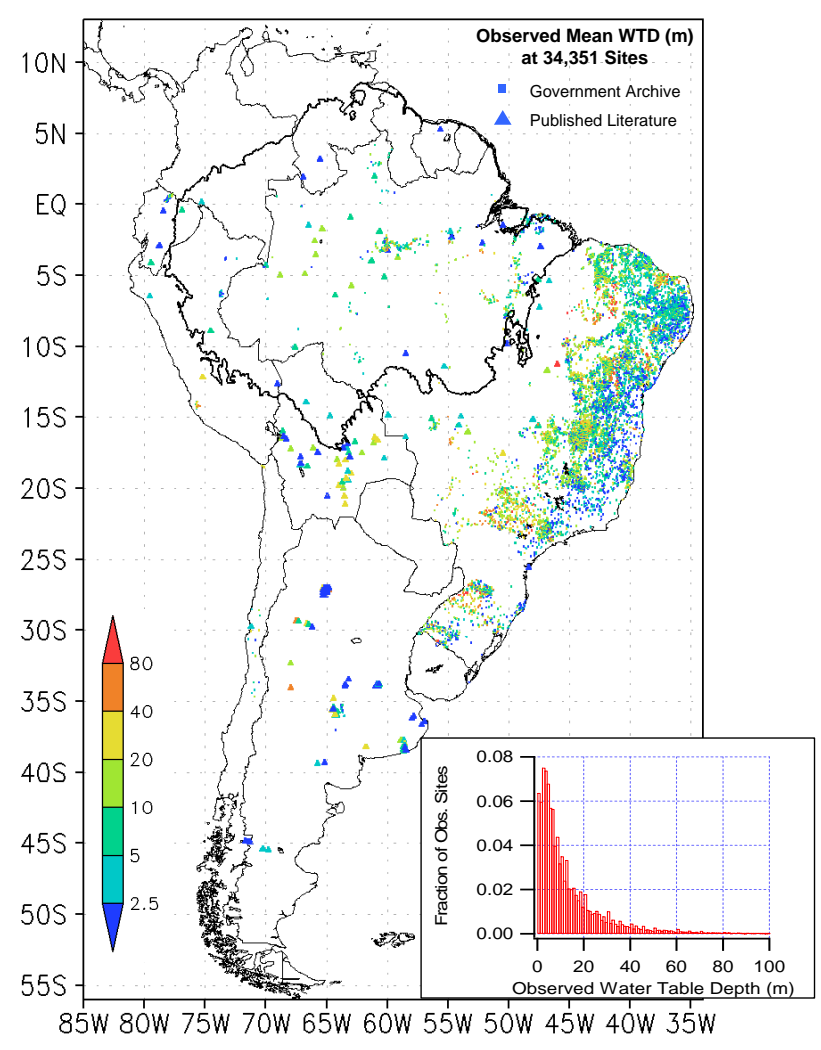

Fig. 1. Observations of water table depth, WTD (m), compiled from government archives and published literature, with the outline of Amazonia ecosystem (inset gives the histogram of WTD).

vs. shallow water table can be revealed. This is the subject of the next section.

\section{Groundwater flow simulation}

We use a groundwater model to simulate the hydrologic equilibrium water table depth over the continent. This equilibrium water table depth reflects the long-term balance between the climate-induced vertical flux $(P$-ET) and terrain-induced lateral divergence from high grounds and convergence into discharge zones. The model was developed and tested in our recent work over N. America using $>567000$ site observations and mapped wetlands (e.g., Fan and Miguez-Macho, 2010). The model concept is simple (Fig. 2a); climate forcing is precipitation $(P)$ minus ET and surface runoff $\left(Q_{\mathrm{s}}\right)$, giving the net flux across the water table, or recharge $(R): R=P-\mathrm{ET}-Q_{\mathrm{s}}$. The latter is redistributed by lateral groundwater divergence under high grounds $(Q)$ and convergence under lowlands, which feeds rivers and wetlands $\left(Q_{\mathrm{r}}\right)$. The water table position is constrained by the sea level along the coast, the ultimate baseline for continental drainage. The resulting water table is an undulating surface beneath land topography, occasionally seen at the surface as springs, wetlands and rivers, and merging with the sea level along the coastline.

At the hydrologic equilibrium, mass balance dictates that in hillslope cells, recharge $(R)$ balances lateral divergence $(Q)$ to the lower neighbors (Fig. 2a):

$R=\sum Q$

And in valley cells, lateral convergence $(Q)$ balances discharge into rivers and wetlands $\left(Q_{\mathrm{r}}\right)$ :

$\sum Q=Q_{\mathrm{r}}$

Equation (2) also applies to coastal cells where groundwater must exit before the sea. River-wetland cells appear naturally in the simulation where water table rises to the land surface as dictated by mass balance. At these cells, the water table is reset at the surface, mimicking river and ET removal in nature $\left(Q_{\mathrm{r}}\right)$. The lateral groundwater flow between cells $(Q)$ is calculated with the Darcy's law and the Dupuit-Forchheimer Approximation (lateral flow only) (see, e.g., Freeze and Cherry, 1979), which relates the water table slope to groundwater flow rate:

$Q=w T\left(\frac{h-h_{\mathrm{n}}}{l}\right)$

where $Q$ is the flow between the center cell and neighbor $n, w$ the width of cell interface, $T$ the transmissivity, $h$ the water table head above sea level, $h_{\mathrm{n}}$ the head in neighbor $n$, and $l$ the distance in between. To obtain $T$ (integration of hydraulic conductivity over depth), we examine two cases (Fig. 2b): water table above (case-a) or below (case-b) the depth $\left(d_{0}\right)$ with known hydraulic conductivity $K_{0}$. The distinction is necessary because global soil datasets do not include information below the top 2-3 $\mathrm{m}$ of land surface, and hence they need to be treated separately. In Case-a, the water table depth $d_{1}$ is shallower than $d_{0}$ and we have,

$$
\begin{aligned}
T & =T_{1}+T_{2}, T_{1}=K_{0}\left(d_{0}-d_{1}\right), T_{2}=\int_{0}^{\infty} K d z^{\prime} \\
& =\int_{0}^{\infty} K_{0} \exp \left(-\frac{z^{\prime}}{f}\right) d z^{\prime}=K_{0} f
\end{aligned}
$$

where $z^{\prime}$ is depth below $d_{0}$, with $K$ assumed to decrease exponentially from $K_{0}$,

$$
K=K_{0} \exp \left(-z^{\prime} / f\right)
$$

where $f$ is the e-folding depth (more below). In Case-b, the water table is $d_{2}$ below the known $K$,

$$
T_{=} \int_{d_{2}}^{\infty} K d z^{\prime}=\int_{d_{2}}^{\infty} K_{0} \exp \left(-\frac{z^{\prime}}{f}\right) d z^{\prime}=K_{0} f \exp \left(-\frac{z-h-d_{0}}{f}\right)
$$

where $z$ is land surface elevation of the center cell. 

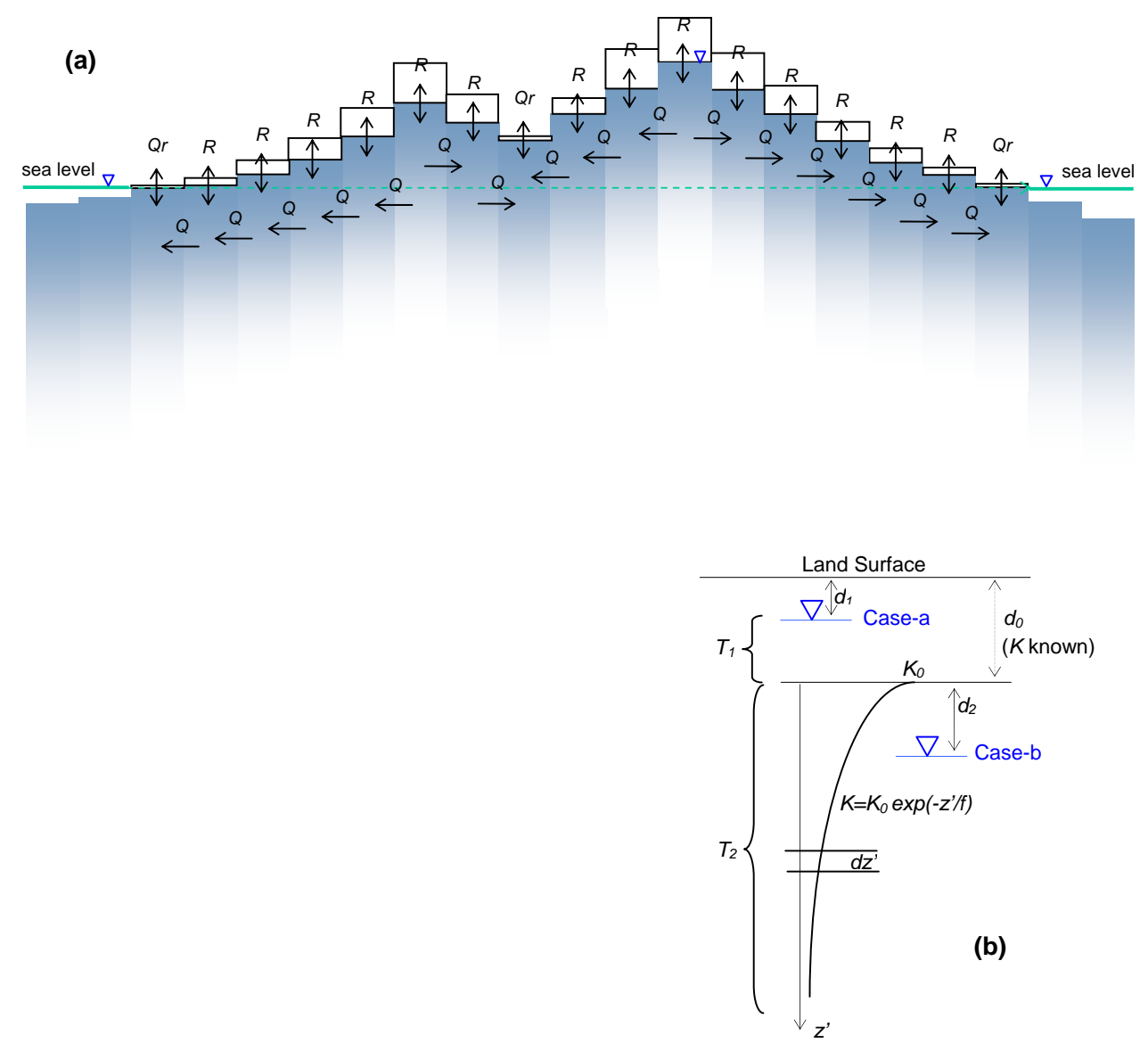

Fig. 2. (a) Schematic of the 2-D groundwater model to simulate the climate (recharge $R$ ), terrain (lateral flow $Q$ ) and sea level (boundary condition) control on water table depth over a continent. In upland cells, recharge balances lateral groundwater divergence to lower neighbors. In valley or coastal cells, lateral groundwater convergence discharges into wetlands and rivers, (b) details of calculating flow transmissivity, $T$, for Case-a, water table within the depth of known soil hydraulic conductivity $(K)$, and Case-b, water table below the known depth where $K$ is assumed to decrease exponentially with depth.

To calculate groundwater flow, hydraulic conductivity $K$ for the geologic material must be known at tens of meters of depth, but global soil datasets do not go below the top 2$3 \mathrm{~m}$ of land surface. Lacking actual measurements, we adopt common assumptions on its vertical distribution. Permeability of the Earth's crust generally decreases with depth (Manning and Ingebritsen, 1999). At the scales of tens of meters, it is widely assumed that the decay is exponential (e.g., Beven and Kirkby, 1979; Jiang et al., 2009), in the form of Eq. (5). The e-folding depth, $f$, reflecting sediment-bedrock profile at a location, depends on the balance among tectonics, in-situ weathering, and erosion-deposition, a complex function of climate, geology and biota. But the balance depends strongly on terrain slope; the steeper the land, the thinner the soil. Climate plays an important role but the mechanisms are more complex; e.g., low rainfall produces low sediment runoff, leading to sediment accumulation and deep soil; high rainfall leads to deeper percolation and denser biota, enhancing in-situ weathering and leading to deeper soil as well. For simplicity with only the first order control, we consider the terrain slope only. The function of $f$ (in $\mathrm{m}$ ) with slope $s$ is determined by calibration to best reproduce water table and wetland observations in N. America (Fan and MiguezMacho, 2010) and takes the form:

$f=\frac{75}{1+150 \mathrm{~s}}, f \geq 4 \mathrm{~m}$

Since there are no continental-scale observations of water table recharge ( $R$ in Eq. (1) and Fig. 2a), it is obtained from four global land surface models as $R=P-\mathrm{ET}-Q_{\mathrm{s}}$ (Fig. 3) where $P$ is observation-based, but ET and $Q_{r m s}$ (surface runoff) are model simulated. The HTESSEL model is the land surface component of the ECMWF GCM (Balsamo et al., 2009). The other three, CLM, MOSAIC, and NOAH, are participants of the NASA's Global Land Data Assimilation System (GLDAS) (Rodell et al., 2004). The four models had been run to simulate the global land hydrology over the past decades. The four models give different estimates of 


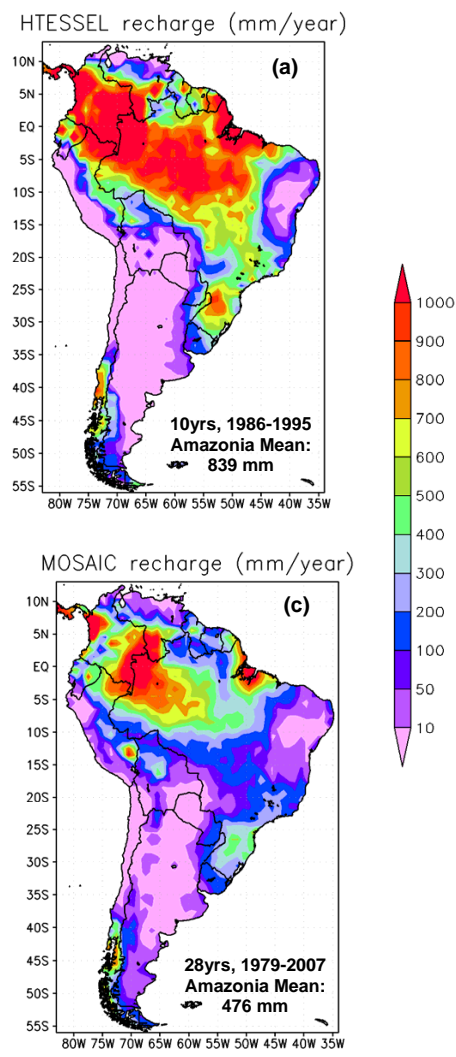

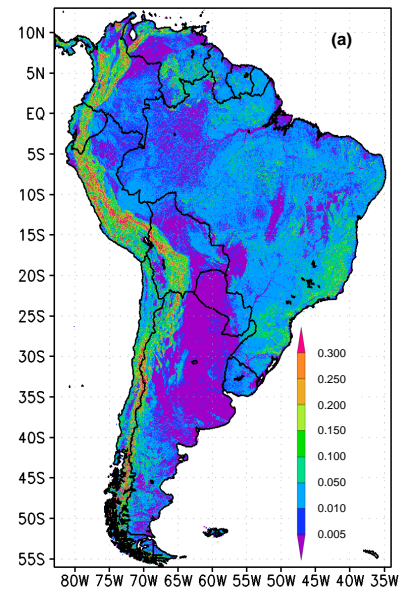
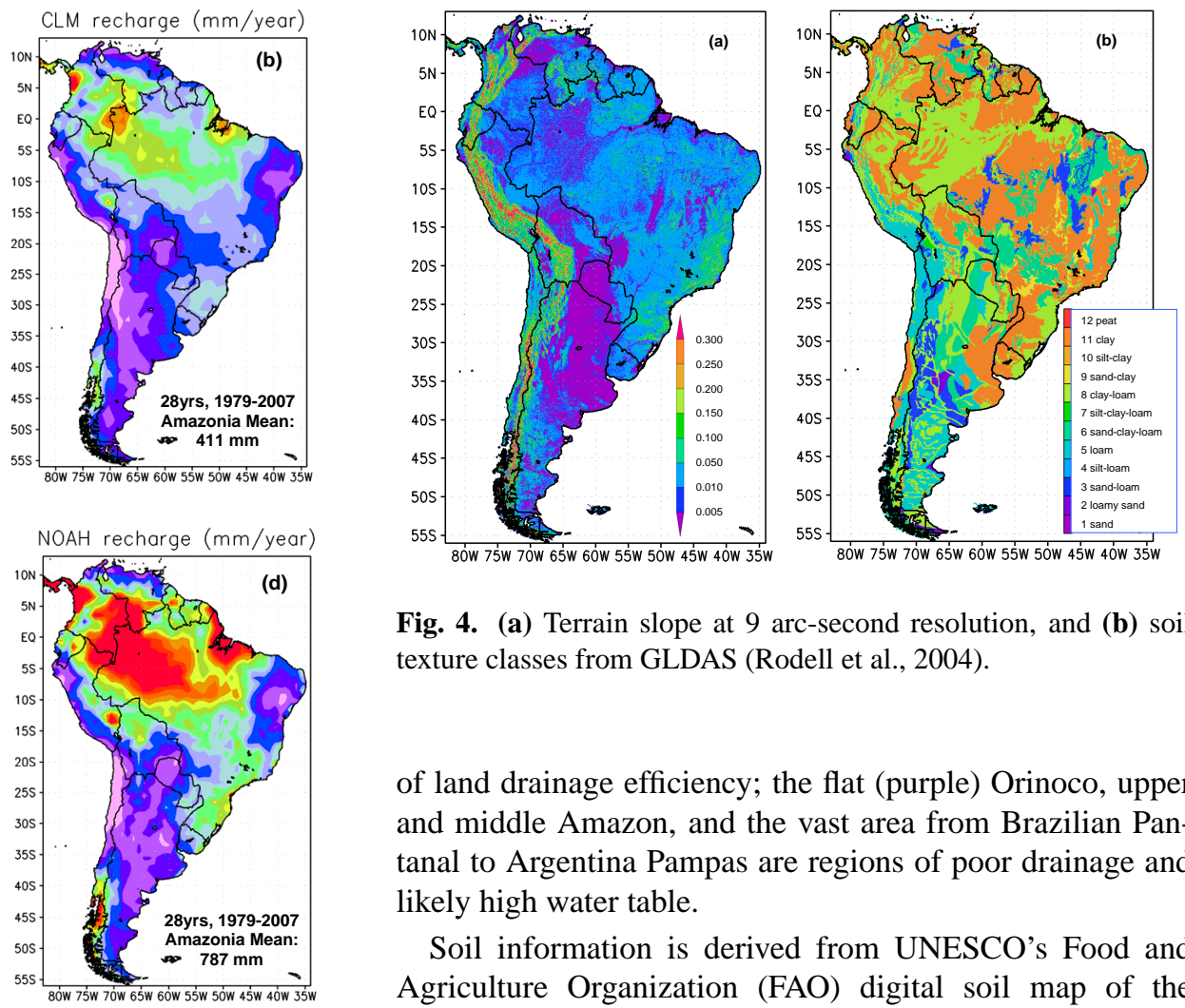

Fig. 3. Mean annual water table recharge $\left(\mathrm{mm} \mathrm{yr}^{-1}\right)$ simulated by four global land surface models: (a) HTESSEL (Balsamo et al., 2009, data from B. van den Hurk), (b) CLM, (c) MOSAIC, and (d) NOAH (last three from GLADS, Rodell et al., 2004).

recharge forcing due to inherent differences in flux parameterization and soil configurations (see Table 1 for soil depth and layer information). We note that CLM gives the lowest recharge estimates in the Amazonia which will result in the deepest water table simulation; everything else equal, a higher $R$ leads to a higher water table. To obtain the range of water table depths due to uncertainties in recharge, we use $R$ from all four models and choose the one that best agrees with WTD observations and gives a conservative (or deeper) estimate of the water table depth and its potential impact on land surface hydrological balance.

Digital topography data, at 3 arc-second resolution, was obtained from the US Geologic Survey (http://hydrosheds. cr.usgs.gov/, last accessed on 14 October 2010) and aggregated to 9 arc-second for the simulation in S. America $(\sim 157 \mathrm{~m} \times 274 \mathrm{~m}$ at the southern tip of the continent, to $\sim 280 \mathrm{~m} \times 274 \mathrm{~m}$ at the Equator), totaling 248103766 cells over the continent and 84184468 in Amazonia. This grid size is a compromise between the need to resolve fine terrain features and computation feasibility. Terrain slope is shown in Fig. 4a, which is used to calculate the rate of decrease in permeability with depth (Eq. 7). It gives the first indication

Fig. 4. (a) Terrain slope at 9 arc-second resolution, and (b) soil texture classes from GLDAS (Rodell et al., 2004).

of land drainage efficiency; the flat (purple) Orinoco, upper and middle Amazon, and the vast area from Brazilian Pantanal to Argentina Pampas are regions of poor drainage and likely high water table.

Soil information is derived from UNESCO's Food and Agriculture Organization (FAO) digital soil map of the world at 5 arc-minute grids. Fractions of silt, clay, and sand are mapped to 12 soil-texture classes defined by the US Department of Agriculture (http://soils.usda.gov/ education/resources/lessons/texture/, last accessed on 14 October 2010). The 12 soil classes (Fig. 4b) are assigned soil hydraulic parameters based on established and commonly adopted procedures (Clapp and Hornberger, 1978). The dominant soil types in the Amazonia are clay-loam (class 8 ) and clay (class 11), both fine-textured and conducive to strong capillary fluxes.

Lateral boundary condition for the water table head is set at sea level along the coast. Although our primary interest is in the Amazonia, the simulation needs to include the entire continent so that the sea level, the true physical boundary condition for water table head, can be used to constrain the model. Starting the initial water table at the land surface, we solve the flow equations iteratively until the mass balance error is less than $1 \mathrm{~mm}$ year ${ }^{-1}$. This is done by first, calculating the lateral flow between the cells based on the initial water table guess using the Darcy's equation, second, checking the mass balance at each cell, and third, adjusting the water table up (if influx $>$ outflux) or down (if influx $<$ outflux) to reduce the imbalance. This procedure is repeated until mass balance error is $<1 \mathrm{~mm}$ year $^{-1}$ at all cells. The simulations, forced by four recharge estimates, are shown in Fig. 5 at the 9 arc-sec resolution $(\sim 274 \mathrm{~m})$.

We note the broad features in WTD distribution common to all four simulations. A shallow water table is found in four types of settings. The first is the humid lowlands of the 
Table 1. Comparison of biases in the simulated WTD using four recharge estimates, for the continental validation.

\begin{tabular}{|c|c|c|c|c|c|c|}
\hline \multirow{2}{*}{$\begin{array}{l}\text { Model (no. layers, } \\
\text { soil depth) }\end{array}$} & \multicolumn{3}{|c|}{ Residual Histogram } & \multirow{2}{*}{$\begin{array}{l}\text { Correlation with } \\
\text { Precipitation }\end{array}$} & \multirow{2}{*}{$\begin{array}{l}\text { Correlation with } \\
\text { Land Elevation }\end{array}$} & \multirow{2}{*}{$\begin{array}{r}\text { Correlation with } \\
\text { Terrain Slope }\end{array}$} \\
\hline & Shift & Stand. Dev. & Skew & & & \\
\hline HTESSEL $(4,2.89 \mathrm{~m})$ & -0.55 & 21.35 & +0.10 & + & -0 & -0 \\
\hline $\operatorname{CLM}(10$, & +1.91 & & +1 & & -0. & -0.3681 \\
\hline $\operatorname{MOSAIC}(3,3.50 \mathrm{~m})$ & -4.36 & 22.38 & -0.34 & +0.2447 & -0.1376 & -0.2814 \\
\hline $\operatorname{NOAH}(4,2.0 \mathrm{~m})$ & +2.66 & 18.19 & +1.11 & +0.0846 & -0.0592 & -0.3484 \\
\hline
\end{tabular}

Orinoco and Amazon basins with high rainfall over a land of poor drainage. The unusually low elevation of the interior Amazon, at such a great distance from its outlet, was marveled at by early explorers (e.g., Wallace, 1889) describing the region as a flat plate with a steep rim (the Andes). The Pastaza-Marañón basins in the Peruvian Amazon, no more than $200 \mathrm{~m}$ above sea level, are down-warped basins as the Andes rose (Clapperton, 1993) and are being actively filled in by sediments derived from the Andes. Drainage in these continental depressions simply cannot keep pace with the high annual rainfall. The second setting is the flat lowlands in semi-arid to arid climate, but nonetheless receiving largescale groundwater convergence, as in the vast region from Mato Grosso of Brazil to the Pampas of Argentina, where the Pantanal, the world's largest freshwater wetland, has developed; in the model, this is a direct result of allowing lateral redistribution of recharge by groundwater flow at inter-cell to continental scales. The third setting is the coastal belt because the water table cannot drop blow the sea level; in the model, this is a direct result of setting the sea level as the lateral boundary condition. The fourth is the river valleys (details in Figs. 9 and 11) dissecting the plateaus of Guyana and Brazilian Highlands where the shallow water table along river corridors is known to support gallery forests in otherwise dry grasslands (Whitmore and Prance, 1987; Clapperton, 1993); in the model, this is a direct result of hillslope to catchment-scale groundwater convergence, a process that hydrologists know very well.

It is seen here that a primary function of the groundwater flow system is to re-organize the land surface surplus (i.e., recharge $R$ ) according to the terrain structure at hillslope to continental scales, with respect to the sea level control on coastal drainage. This terrain structure and sea level control may over-ride climate control in many cases in maintaining a high water table, such as in the Pampas region of Argentina, the river corridors in the Cerrados of eastern Brazil, and the arid valleys and coastal zones in Peru and Chile.

\section{Validation of WTD simulations}

We validate the simulations with all available observations, first over the continent, second over the Amazonia, and third at nine research sites reported in the literature.
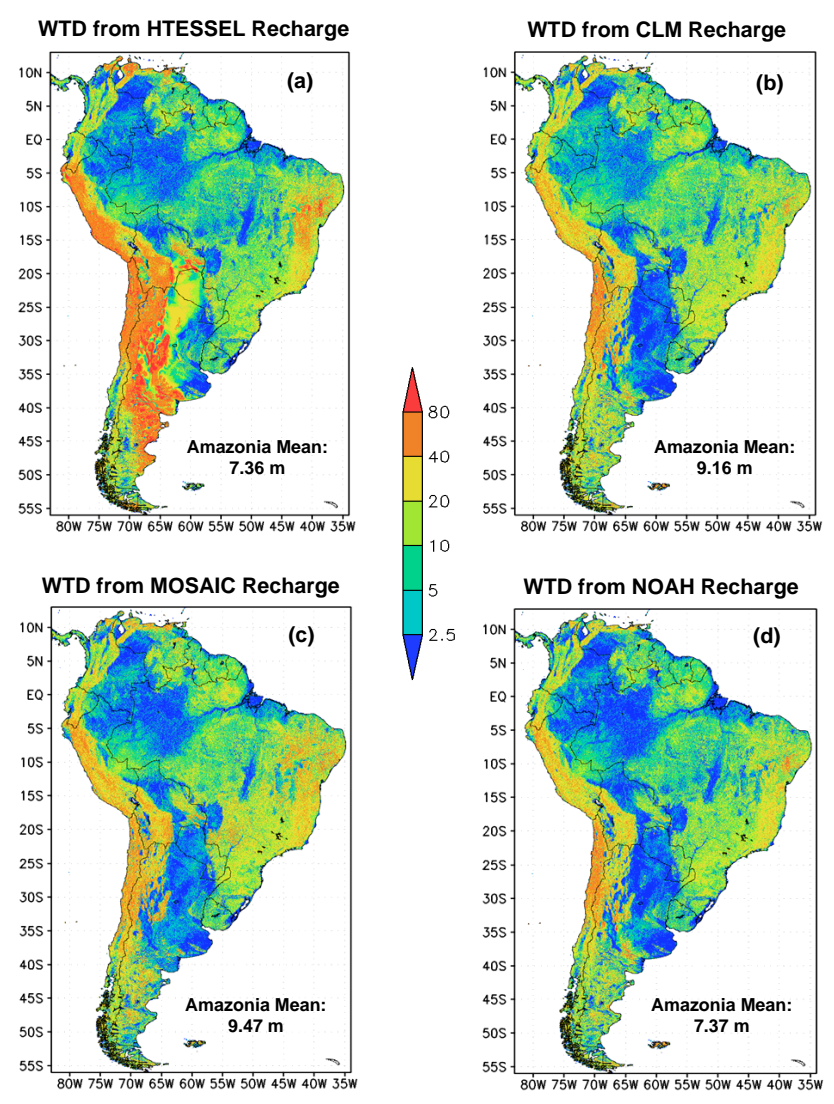

Fig. 5. Simulated equilibrium water table depth (m) forced by recharge from (a) HTESSEL, (b) CLM, (c) MOSAIC, and (d) NOAH.

\subsection{Over the continent}

The 34351 site observations (Fig. 1) fall into 27947 model cells over the continent. We examine the model residual (simulated - observed head). Without systematic biases, the residual should follow a zero-mean and symmetrical distribution with no dependence on climate or terrain but allowance for random deviations due to coarse grids $(\sim 274 \mathrm{~m}$ cell vs. well/point observations), generalization in geology (neglecting aquifer heterogeneity) and the temporal noise (observations taken at different times). Table 1 summarizes the 


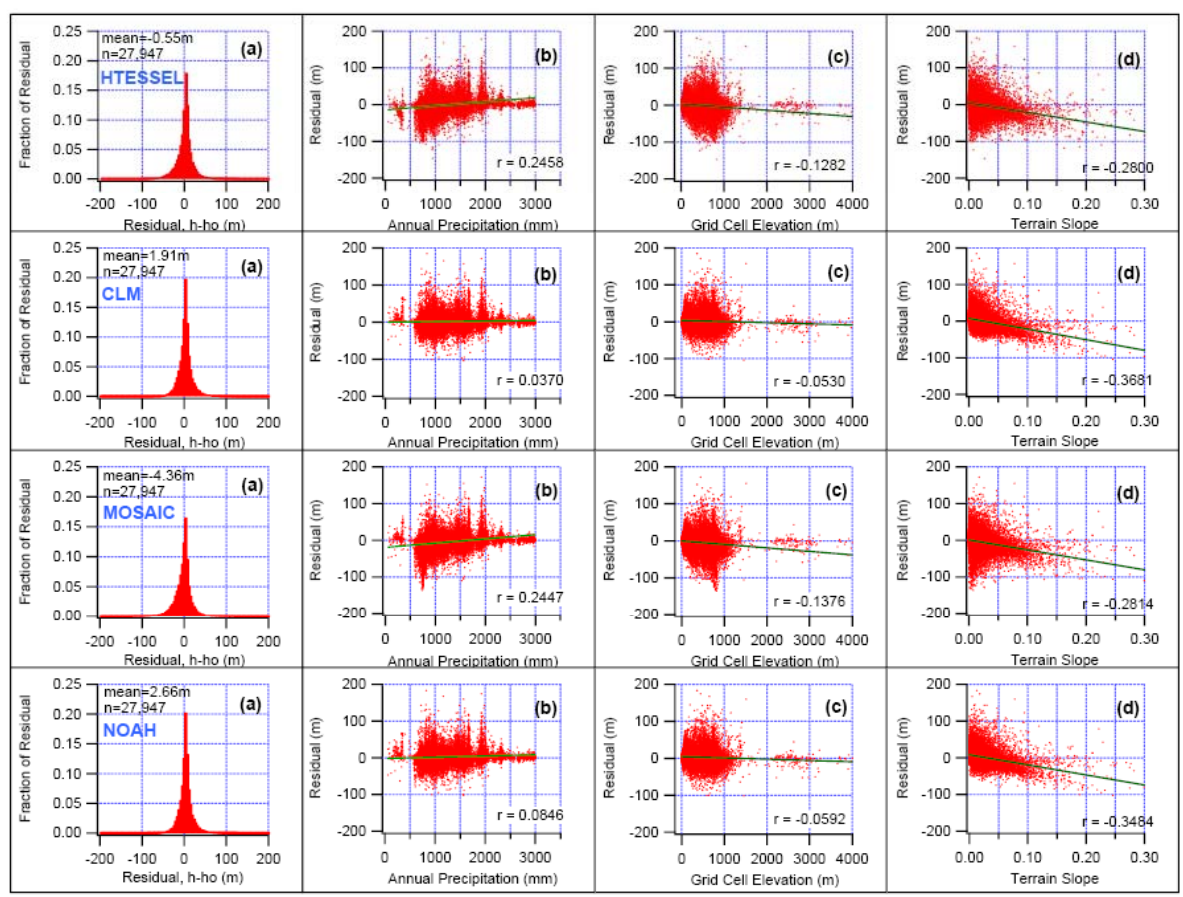

Fig. 6. Residual statistics for the four simulations: (a) histogram of the residual (modeled head - observed head), (b) residual vs. annual precipitation, (c) vs. land elevation, and (d) vs. terrain slope, with the Pearson correlation coefficient $(r)$ given.

residual statistics, and Fig. 6 plots the residual histogram (a), dependence of residual on annual precipitation (b), land elevation (c) and slope (d), from the four recharge forcings. The simulation using HTESSEL recharge has the smallest continental mean residual $(-0.55 \mathrm{~m}$, i.e., simulation $0.55 \mathrm{~m}$ too low compared to observations); Mosaic has the largest residual ( $-4.36 \mathrm{~m}$, simulation $4.36 \mathrm{~m}$ too low); CLM and NOAH both have a positive residual $(1.91 \mathrm{~m}$ and $2.66 \mathrm{~m}$ too high, respectively). Because the observations likely contain a low bias due to pumping, the CLM and NOAH forced simulations may be closer to the natural water table conditions. Common among the four is a negative residual correlation with terrain slope, that is, the positive model-bias occurs mainly in flat areas, consistent to the notion of low bias in observations due to pumping which occurs at flat lands where cities, industries and agriculture are located.

\subsection{Over the Amazonia}

Validation statistics over the Amazonia (outline in Fig. 1), where 2511 grid cells have observations, is given in Table 2 and Fig. 7. The CLM-forced simulation has the smallest mean bias, but even CLM, the lowest recharge over the Amazon (Fig. 3), produces a water table that is $2.31 \mathrm{~m}$ too high compared to the observations. Groundwater pumping, clustered over large metro regions in Amazonia is again thought to be a cause; large cities such as Manaus, Belém, Santarém, Rio Branco, and Boa Vista, situated on major aquifers, are partially, and the city of Vilhena is entirely, supplied by groundwater. In the state of Maranhão (capital being São Luís), 70\% of the water supply for its cities comes from the groundwater. The fact that these observations are in dense clusters over major cities further enhances their influence on the statistics because any pumping well in the cluster would affect all the other wells nearby. The mostly eliminated groundwater recharge over urban pavements also contributes toward the low bias (http://www.ana.gov. br/pnrh_novo/documentos/01\%20Disponibilidade $\% 20 \mathrm{e} \%$ 20Demandas/VF\%20DisponibilidadeDemanda.pdf, last accessed on 14 October 2010). However, it is difficult to remove these effects without some degree of arbitrary manipulation of the data, and thus we use them here but recognize the biases.

Another possible cause is that even the CLM recharge, the lowest of the four GLDAS model estimates, contains a positive bias. The GLDAS land models did not include the water table as a source of ET, and if indeed the water table is an important source as hypothesized here, then these models may have likely under-estimated the ET and overestimate the recharge. Figure 8 shows the 30 year mean water balance as simulated by CLM, with precipitation $(P)$ based on observations. The mean ET rate in the Amazon (Fig. 8b) is in the range of $3.0-4.5 \mathrm{~mm} \mathrm{day}^{-1}$, very close to the observations and model synthesis of $3.75 \mathrm{~mm} \mathrm{day}^{-1}$ by Fisher et al. (2009). It suggests that CLM mean soil water balance, and hence the soil water drainage or water table 
Table 2. Same as Table 1, but over the Amazonian ecosystem (outline in Fig. 1).

\begin{tabular}{lrrrrrr}
\hline Model (no. layers, & \multicolumn{3}{c}{ Residual Histogram } & Correlation with & Correlation with & $\begin{array}{r}\text { Correlation with } \\
\text { soil depth) }\end{array}$ \\
\cline { 2 - 4 } Shift & Stand. Dev. & Skew & Precipitation & Land Elevation & Terrain Slope \\
\hline HTESSEL $(4,2.89 \mathrm{~m})$ & +4.36 & 8.59 & +1.63 & -0.1073 & +0.0902 & -0.0955 \\
CLM $(10,3.44 \mathrm{~m})$ & +2.31 & 8.71 & +1.52 & -0.0779 & +0.0454 & -0.1827 \\
MOSAIC $(3,3.50 \mathrm{~m})$ & +2.75 & 8.80 & +1.37 & -0.0040 & -0.0076 & -0.1755 \\
NOAH $(4,2.0 \mathrm{~m})$ & +4.11 & 8.65 & +1.74 & -0.0825 & +0.0679 & -0.1136 \\
\hline
\end{tabular}

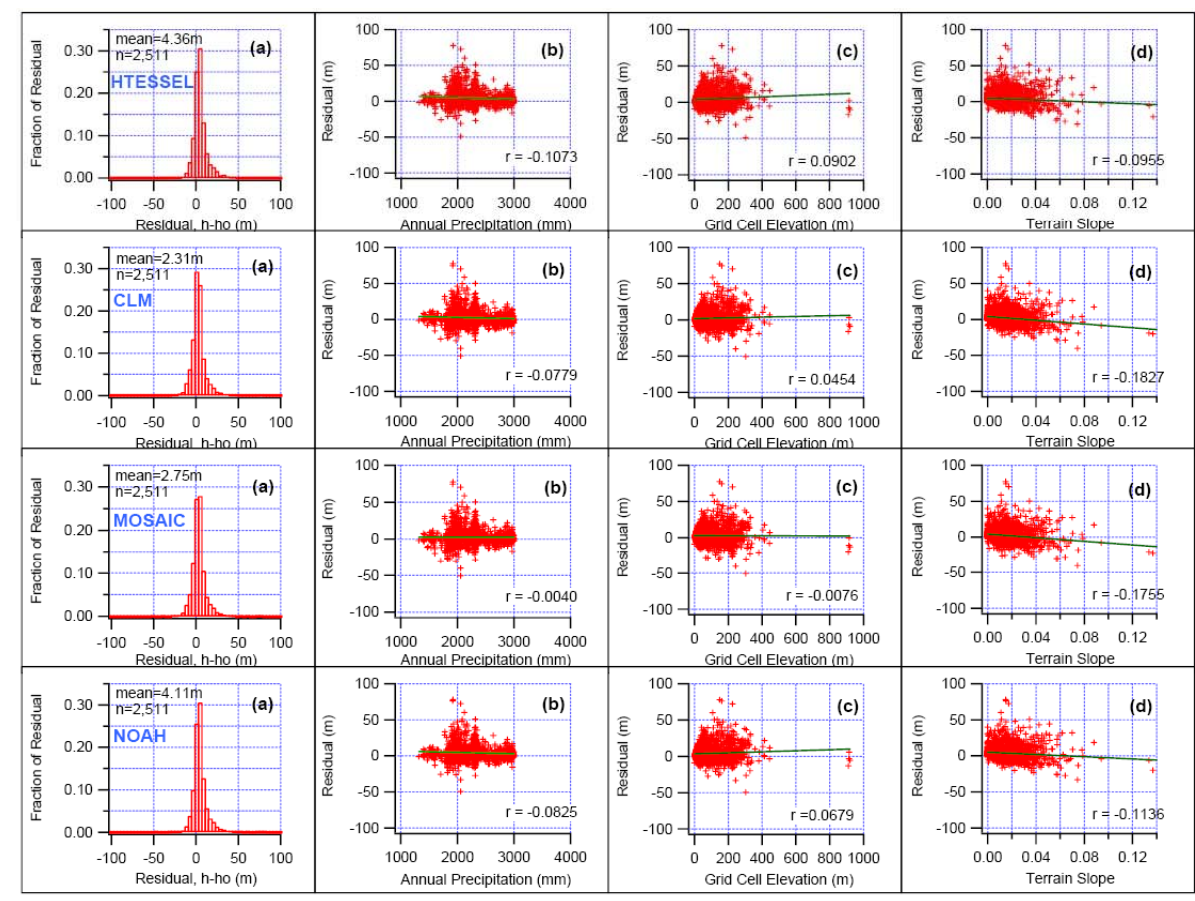

Fig. 7. Same as Fig. 6, but for validation over the Amazonia (outline shown in Fig. 1).

recharge, is reasonable. However, recharge is calculated as $R=P-\mathrm{ET}-Q_{\mathrm{s}}$, where $Q_{r m s}$ is surface runoff, so biases in $Q_{r m s}$ also matter. There are no surface runoff observations to assess $Q_{r m s}$, and the issue of possible recharge bias remains unsolved. An estimate of recharge as a result of water table feedbacks can only be achieved by coupled soil water and groundwater simulations which is the intention of our future work. In this paper, we keep our analysis simple and attempt to provide a preliminary water table assessment from available recharge estimates.

We note that the large residual standard deviation in Tables 1 and 2 have several causes. First, the mean water table depth over the grids of $\sim 274 \mathrm{~m}$ are compared with well observations taken at a point, and depending on whether the point is on the hilltop or at the valley bottom, the observed water table can vary. For example, in the Ducke Reserve near Manaus (Cuartas, 2008), the water table head can differ by $>30 \mathrm{~m}$ within the span of a grid cell. Second, groundwater pumping can lower the local water table by tens of meters, rendering the observations greatly different from the natural conditions which the model attempts to simulate. Third, heterogeneity in local permeability is neglected due to the lack of actual permeability data across the continent. Instead, a uniform parameterization is applied which considers only the influence of terrain slope on soil depth. While this may work well over the continent statistically, it can misrepresent local conditions and causing the large deviation between model and observations. Fourth, while the model attempts to simulate a hydrologic equilibrium condition, the observations are taken at various times over several decades; nearly all of the sites have only one reading, that is, each observation point has a different time stamp. This introduces a large temporal noise that also causes a large deviation between model and observations. Thus the large standard deviation is a result of inherent deficiencies in the observations (point nature, groundwater pumping, and temporal noise) and the 

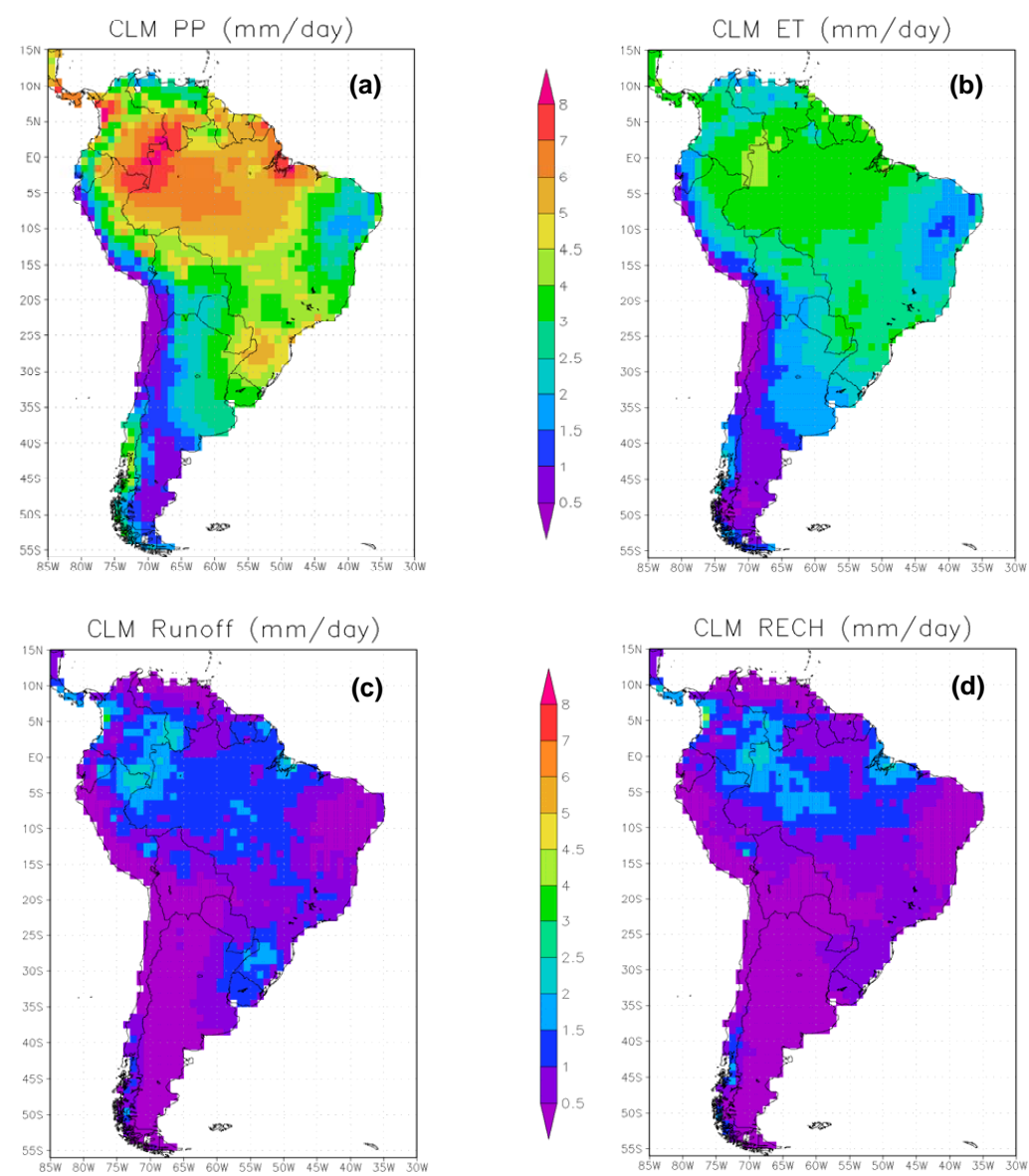

Fig. 8. CLM long-term (1979-2008) mean water balance: (a) precipitation $P$, (b) ET flux, (c) surface runoff $Q_{r m s}$, and (d) water table recharge $R$, all in $\mathrm{mm} / \mathrm{day}$. The latter is estimated as $R=P-\mathrm{ET}-Q_{\mathrm{s}}$.

simple parameterization of permeability in the absence of actual measurements. These issues cannot be resolved by this study alone without fundamental improvement in the observational dataset, detailed characterization of local aquifers over the continent, and greater computational power. However, our goal is to provide a first-order assessment of the water table position and its potential influence on land surface fluxes. The result may illustrate the need to improve groundwater observations and subsurface datasets in support of better large-scale groundwater models.

\subsection{At nine research sites reported in the literature}

As a third step of validation, we zoom into various study sites reported in the literature and examine how well the simulated water table compares with local observations where they are available. In particular, we assess how well the model reproduces the observed spatial patterns along the topographic gradient. A search of literature found nine sites in Amazonia with WTD reports (Fig. 9). These research sites are not affected by groundwater pumping based on the descriptions

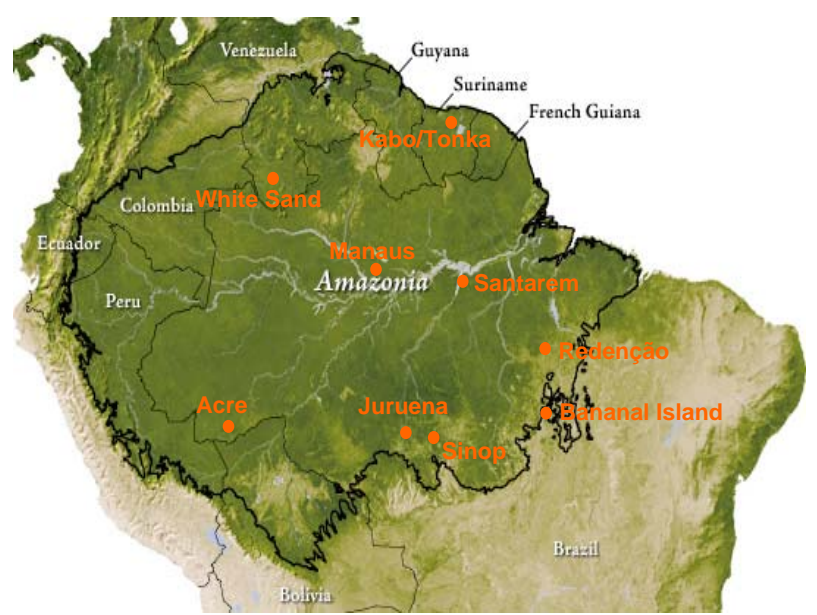

Fig. 9. Sites of detailed validation using water table observations from published literature (base-map: vegetation index from $R$. Simmon, NASA Earth Observatory). 

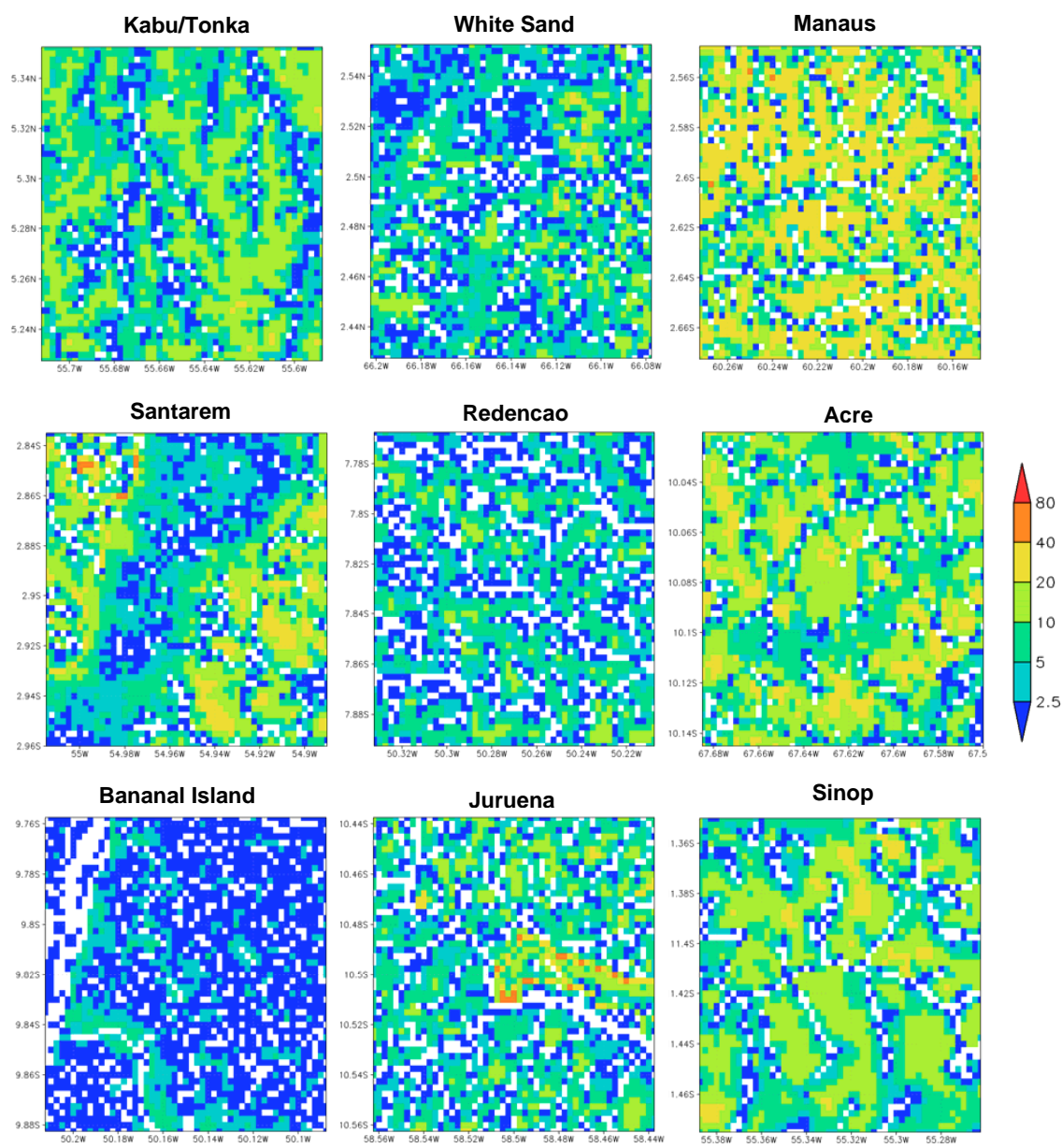

Fig. 10. Simulated WTD $(\mathrm{m})$ surrounding the nine sites (Fig. 9) with WTD observations (white cell = WTD at land surface).

given in the articles. The reported WTD are compared with the simulation forced by CLM (smallest bias, lowest recharge and deepest water table). The simulated WTD over a $50 \times 50$ cell area surrounding the sites is shown in Fig. 10. Comparisons between simulated and observed WTD at three characteristic topographic positions (valley, mid-slope, and plateau) are given in Table 3 and plotted in Fig. 11. Note that the large range in both the observed and simulated WTD is due to the fact that the exact location of observations are not given in the articles but only described as valley (or low-ground), midslope (or mid-ground) and plateau (or high-ground) or similar categories. The simulated counterparts are also broadly defined, with the range of WTD in Table 3 and Fig. 11 based on the maps in Fig. 10. This general comparison suggests that the CLM-forced simulation is accurate in the valleys as expected, as they are groundwater convergence zones, but it is deeper than observed under mid-grounds and high-grounds in seven of the nine cases.

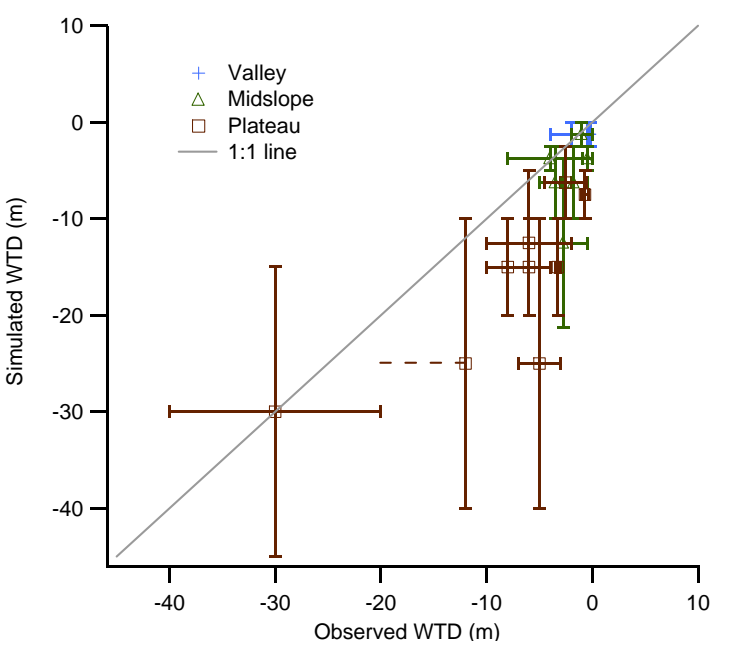

Fig. 11. Comparison of simulated and observed water table depth (m) at the nine sites (data in Table 3). 
Table 3. Information on the 9 sites for detailed validation and comparison between observed and simulated WTD (forced by CLM).

\begin{tabular}{|c|c|c|c|c|c|c|c|c|c|c|c|c|}
\hline \multirow{2}{*}{ Site and Source } & \multicolumn{3}{|c|}{ Location } & \multirow{2}{*}{ Annual P (mm) } & \multirow[t]{2}{*}{ Soil } & \multirow{2}{*}{ Vegetation } & \multicolumn{3}{|c|}{ Observed WTD (m) } & \multicolumn{3}{|c|}{ Simulated WTD* (m) } \\
\hline & Latitude $^{\circ}$ & Longitude $^{\circ}$ & Elevation, $\mathrm{m}$ & & & & valley & midslope & plateau & valley & midslope & plateau \\
\hline $\begin{array}{l}\text { Kabo/Tonka (Poels, } \\
\text { 1987) }\end{array}$ & 5.29 & -55.65 & $30-50$ & 2116 & sandy loam & $\begin{array}{l}\text { dense evergreen } \\
\text { forest }\end{array}$ & $0-1$ & $2-5$ & $4-8$ & $0-2.5$ & $2.5-10$ & $10-20$ \\
\hline $\begin{array}{l}\text { White Sand } \\
\text { (Bongers et al., } \\
\text { 1985; Coomes and } \\
\text { Grubb, 1996) }\end{array}$ & 2.49 & -66.14 & $99-105$ & $2600-3600$ & bleached sand & $\begin{array}{l}\text { palm forest to } \\
\text { short caatinga }\end{array}$ & $0-0.4$ & $0-0.9$ & $0.4-1$ & $0-2.5$ & $2.5-5$ & $5-10$ \\
\hline $\begin{array}{l}\text { Manaus (Cuartas, } \\
\text { 2008; Hodnett et } \\
\text { al., 1997a, 1997b) }\end{array}$ & -3.13 & -60.12 & $30-120$ & $1800-2800$ & clay loam & $\begin{array}{l}\text { dense evergreen } \\
\text { forest }\end{array}$ & $0-0.5$ & $0.5-5$ & $20-40$ & $0-2.5$ & $2.5-20$ & $20-40$ \\
\hline $\begin{array}{l}\text { Santarem (Nepstad } \\
\text { et al., 2002) }\end{array}$ & -2.897 & -54.952 & $\sim 160$ & 2000 & $\begin{array}{l}\text { Oxisol rich in } \\
\text { kaolinite clay }\end{array}$ & $\begin{array}{l}\text { dense evergreen } \\
\text { forest }\end{array}$ & & & $>12$ & $0-2.5$ & $2.5-10$ & $10-40$ \\
\hline $\begin{array}{l}\text { Redenção (Grogan } \\
\text { and Galvao, 2006) }\end{array}$ & -7.83 & -50.27 & $220-250$ & $1700-1900$ & $\begin{array}{l}\text { varied sand } \\
\text { shallow rock }\end{array}$ & $\begin{array}{l}\text { transitional ever- } \\
\text { green forest }\end{array}$ & $0-4$ & $0-8$ & $2-10$ & $0-2.5$ & $2.5-5$ & $5-20$ \\
\hline $\begin{array}{l}\text { Acre (Selhorst et } \\
\text { al., 2003) }\end{array}$ & -10.0831 & -67.6236 & $\sim 220$ & 1640 & Oxisol & evergreen forest & & $3-9$ & $6-10$ & $0-2.5$ & $2.5-10$ & $10-20$ \\
\hline $\begin{array}{l}\text { Bananal Island } \\
\text { (Borma et al., } \\
\text { 2009) }\end{array}$ & -9.82 & -50.15 & $170-182$ & 1656 & $\begin{array}{l}\text { hydromorphic } \\
\text { sand }\end{array}$ & $\begin{array}{l}\text { flooded savvana } \\
\text { and forest }\end{array}$ & $0-2$ & $0-2$ & $0.6-4.5$ & $0-2.5$ & $0-2.5$ & $2.5-10$ \\
\hline $\begin{array}{l}\text { Juruena (Jirka et al., } \\
\text { 2007) }\end{array}$ & -10.50 & -58.50 & $240-280$ & 2200 & clay loam & $\begin{array}{l}\text { ecotone } \\
\text { rainforest } \\
\text { - savanna }\end{array}$ & $0-1$ & $0.5-3$ & $3-7$ & $0-2.5$ & $2.5-10$ & $10-40$ \\
\hline $\begin{array}{l}\text { Sinop (Vourlitis et } \\
\text { al., 2008) }\end{array}$ & -11.4125 & -55.325 & 335 & 1857 & $\begin{array}{l}\text { quartzarenic } \\
\text { neosol - sandy }\end{array}$ & $\begin{array}{l}\text { tropical semi- } \\
\text { deciduous forest }\end{array}$ & & & $3-3.5$ & $0-2.5$ & $2.5-10$ & $10-20$ \\
\hline
\end{tabular}

* Corresponds to the center area of the images in Fig. 10.

In summary, the validations with point observations over the continent and the Amazonia suggest that the simulations in general have no systematic biases along climate and terrain gradients, but all four give a WTD that is shallower than observed in the Amazonia. Likely causes are the low bias in the observations from pumping and possible high bias in GLDAS recharge estimates. To be conservative, we use the simulation from the lowest recharge in the Amazon (CLM) for the remainder of the study. We note that the CLM-forced WTD, when compared with detailed observations at nine sites, appears accurate in the valleys but too deep under mid and high grounds, which may under-estimate its potential influence on the land surface in upland ecosystems.

Based on the CLM-forced simulation, $36 \%$ of the area in Amazonia has a WTD $<5 \mathrm{~m}$, and $60 \%<10 \mathrm{~m}$. This is close to the observations where $34 \%$ has a WTD $<5 \mathrm{~m}$, and $57 \%$ $<10 \mathrm{~m}$. Note that groundwater observations for exploitation purposes are rarely made in swampy and inhabitable regions where the WTD is at or above the surface, and hence such conditions may be under-sampled. The extremely steep or arid regions are also likely under-sampled. In this sense, the simulated WTD distribution may better reflect the natural range and distributions of WTD.

The potential influence of the water table on land surface depends not only on its depth but also on the soil characteristics that control the strength of capillary flux. Next we calculate the upward soil capillary flux the soils of the Amazon can potentially support from the simulated WTD distribution based on simple calculations.

\section{Calculating potential soil capillary flux from the water table}

Soil water movement occurs in 3 vertical zones (Fig. 12a). Above the water table, the soil is unsaturated, and both capillary force ( $C$, upward or downward) and gravity forces $(G$, downward) drive the flux; below the water table, the soil is fully saturated and gravity drives the lateral exchange with the neighboring area depending on the water table slope. Above the water table is a zone of saturation termed capillary fringe (or tension-saturated-zone). The physics of soil water movement in a column is described by the Richards Equation, solved in most land surface components of climate and ecosystem models. We use the Clapp-Hornberger (1978) soil water retention relation and solve the Richards Equation numerically for the two dominant soil types in the Amazonia (clay-loam and clay, Fig. 4b), with a prescribed boundary condition of wilting point in the top layer (all layers are $0.05 \mathrm{~m}$ thick) and saturation in the layer containing the water table. The resulting soil moisture profiles and capillary fluxes are shown in Fig. 12b for the two soil types. The soil moisture profiles indicate that the water table can keep the shallow soils above their wilting point for all water table depths 
(a)

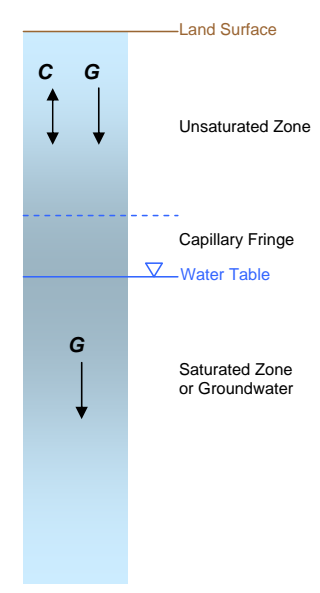

(b)

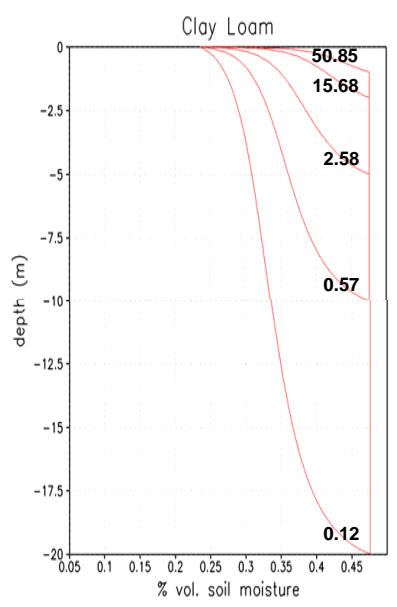

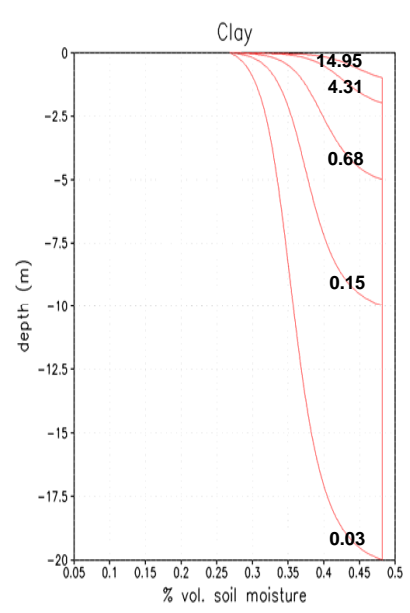

Fig. 12. (a) Typical soil water zones. Upward and downward capillary fluxes $(C)$ and downward gravity flux $(G)$ drive soil water movement above the water table, and gravity $(G)$ drives the flow below the water table. (b) Soil moisture profile and upward capillary flux (mm day ${ }^{-1}$ ) calculated from the Richards Equation, with wilting point prescribed in the top $0.05 \mathrm{~m}$ and saturation at the water table of various depths (1, 2, 5, 10, and $20 \mathrm{~m}$ ), for the two most abundant soil types in the Amazon (clay-loam and clay).

examined here (1-20 m). Upward capillary fluxes from the water table are very large with WTD $<2 \mathrm{~m}$ but decreases rapidly as the water table drops deeper, similar to an exponential decay.

Before applying the above method to the Amazon, two issues must be addressed. First, the theoretical maximum flux obtained above exceeds the potential evaporation rate at shallow water table depths (Fig. 12b), because the latter is limited by available energy, atmospheric vapor pressure and turbulence, and diffusion kinetics, but the former is entirely driven by the metric potential between the dry top and the saturated water table. To address this issue, we place a cap of $5 \mathrm{~mm}$ day $^{-1}$ to the solution of Richards Equation. This cap is below the maximum observed ET; globally, closed canopy tropical forests can evaporate up to $2 \mathrm{~m}$ year $^{-1}$, or $5.5 \mathrm{~mm} \mathrm{day}^{-1}$ (Gordon et al., 2005); estimates of ET from a wet forest in Costa Rica, based on two methods (PenmanMontieth and Priestly-Taylor), are 5.2 and $6.3 \mathrm{~mm} \mathrm{day}^{-1}$ in 1998 and 1999 respectively (Loescher et al., 2005). Thus a cap of $5 \mathrm{~mm} \mathrm{day}^{-1}$ used here is considered reasonable.

The second issue is that the Amazonian surface soil on the valley floors may never dry down to the wilting point due to the presence of a shallow water table maintained by continuous groundwater convergence. Hence the combination of a wilting-point top soil and a shallow water table is theoretically inconsistent. To address this problem, we solve the Richards Equation with a prescribed top soil at 50\% saturation (mid point between wilting point and porosity). The resulting capillary flux is $>5 \mathrm{~mm} \mathrm{day}^{-1}$ if WTD is $<3.55 \mathrm{~m}$ in the clay-loam soil and $<1.8 \mathrm{~m}$ in the clay soil. The water table in the valleys is generally shallower than these values and therefore the capillary flux is greater than $5 \mathrm{~mm} \mathrm{day}^{-1}$. That is, the $5 \mathrm{~mm} \mathrm{day}^{-1}$ cap discussed in the earlier paragraph has effectively addressed this issue.

We applied the above method (with the cap) to the Amazon water table and soils. Figure 13 gives the CLM-forced WTD simulation in the Amazon, with details at nine sites that have ET estimates. Based on this equilibrium WTD map and the soil types in the Amazon (Fig. 4b), we calculate the capillary flux, cap it under $5 \mathrm{~mm} \mathrm{day}^{-1}$, and aggregate it from 9 arcsecond (WTD grid) to 1 arc-minute ( $\sim 2 \mathrm{~km}$, footprint of flux towers). The resulting flux over the Amazonia is shown in Fig. 14. Averaged over the Amazonia, it is $2.1 \mathrm{~mm} \mathrm{day}^{-1}$, compared to the annual mean ET of $\sim 3.8 \mathrm{~mm} \mathrm{day}^{-1}$ estimated by Fisher et al. (2009). At the nine sites with ET estimates in Fig. 14, the potential capillary flux (upper number) and the annual (wet and dry season) mean ET (lower number) are given. Where the water table is shallow only in the valleys (Jaru, Guyaflux), the potential capillary flux over a $2 \mathrm{~km}$ grid at the site is $<1 \mathrm{~mm} \mathrm{day}^{-1}$, and where it is shallow over broader areas (Acre, Bananal Island), the flux can be $>3 \mathrm{~mm}_{\text {day }}{ }^{-1}$. Weak capillarity in sandy soils in KabuTonka (Poels, 1987) and Sinop (Vourlitis, 2008) reduces the potential water table influence. We note that although we made a comparison of the potential capillary flux to the estimated actual ET, the former is the maximum capillary flux that can occur in the Amazon if the surface soil is at wilting point. It is meant to illustrate the possible rate of this flux if such dry condition occurs, and hence is not directly comparable to the actual ET which is used here only to provide a reference. 


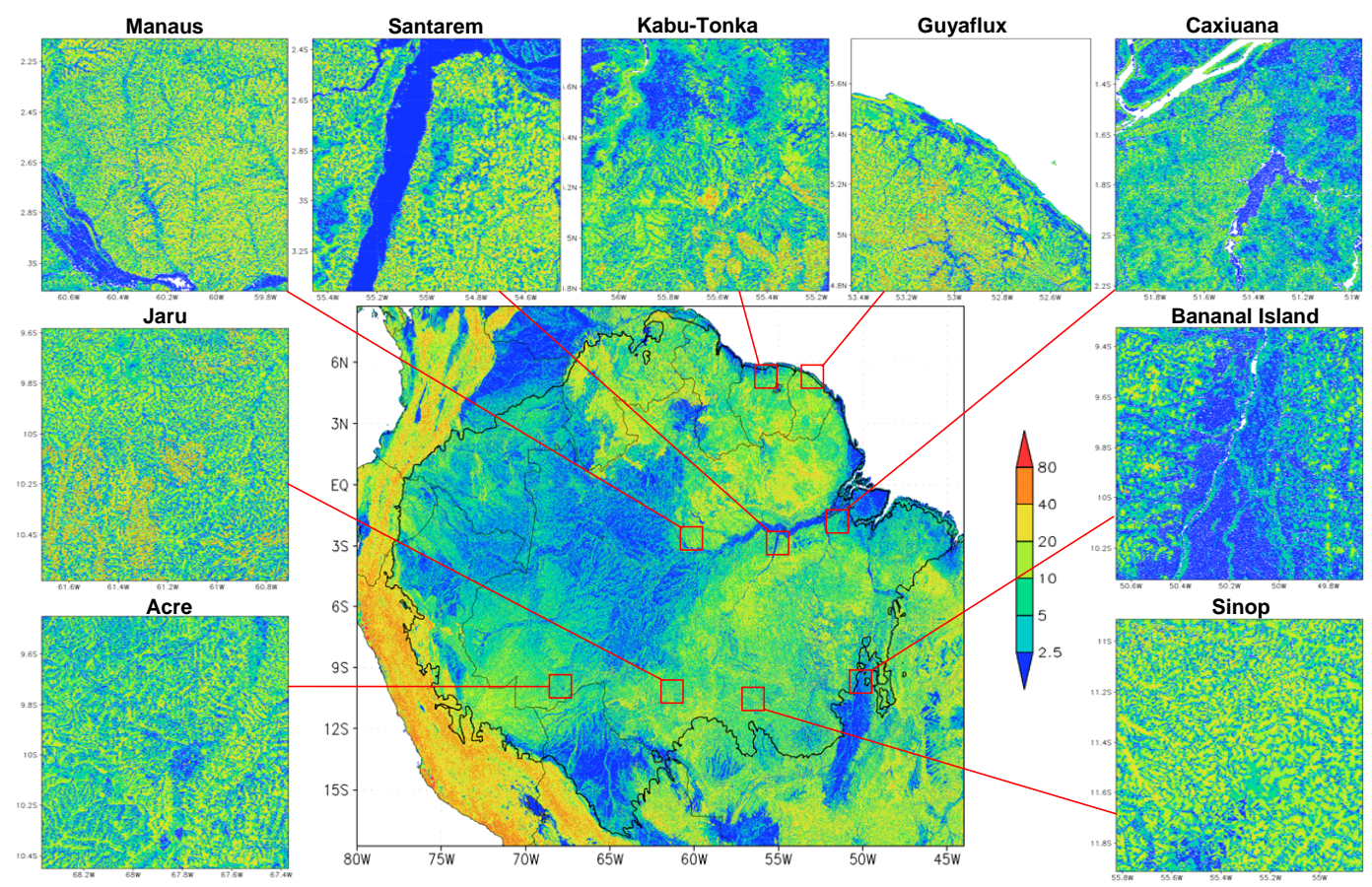

Fig. 13. Spatial details in the CLM-forced WTD simulation (m) in Amazonia and around the nine sites with independent ET estimates (white cells $=$ WTD at land surface).

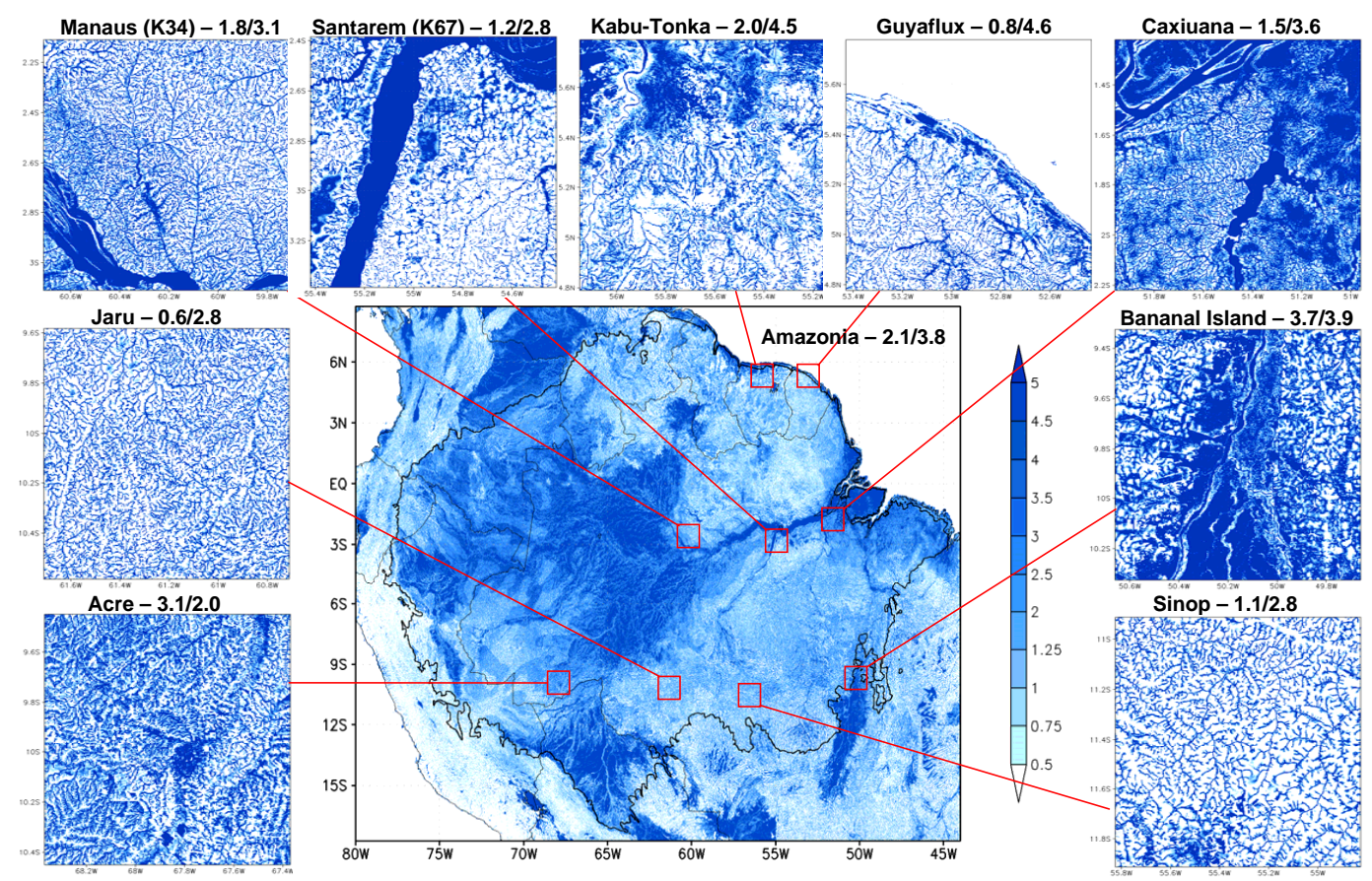

Fig. 14. Calculated equilibrium potential capillary flux $\left(\mathrm{mm} \mathrm{day}^{-1}\right)$ from the CLM-forced water table simulation in the Amazonia, with details around nine sites with ET estimates. The numbers given are potential capillary flux from the water table over annual mean (dry and wet season) total ET, both in mm day ${ }^{-1}$. ET source: Manaus, Santarem, Caxiuana, Jaru and Sinop (Juarez et al., 2007), Bananal Island (Borma, et al., 2009), Guyaflux and Amazonian mean (Fisher et al., 2009), Kabu-Tonka (Poels, 1987), Acre (Duarte et al., 2008). 
Table 4. WTD and capillary flux $\left(\mathrm{mm} \mathrm{day}^{-1}\right)$ over the flux-tower footprint $(\sim 2 \mathrm{~km})$ from four simulations at nine sites with independent ET estimates and the mean over the Amazonia.

\begin{tabular}{|c|c|c|c|c|c|c|c|c|c|}
\hline \multirow[t]{2}{*}{ Site } & \multicolumn{2}{|c|}{$\begin{array}{c}\text { CLM } \\
(R=411 \mathrm{~mm})\end{array}$} & \multicolumn{2}{|c|}{$\begin{array}{c}\text { MOSAIC } \\
(R=476 \mathrm{~mm})\end{array}$} & \multicolumn{2}{|c|}{$\begin{array}{c}\text { NOAH } \\
(R=787 \mathrm{~mm})\end{array}$} & \multicolumn{2}{|c|}{$\begin{array}{c}\text { HTESSEL } \\
(R=839 \mathrm{~mm})\end{array}$} & \multirow[t]{2}{*}{$\begin{array}{c}\text { Independent ET Estimate } \\
\left(\mathrm{mm} \mathrm{day}^{-1}\right)\end{array}$} \\
\hline & WTD (m) & $\begin{array}{c}\text { Flux } \\
\left(\mathrm{mm} \mathrm{day}^{-1}\right)\end{array}$ & WTD (m) & $\begin{array}{c}\text { Flux } \\
\left(\mathrm{mm} \mathrm{day}^{-1}\right)\end{array}$ & WTD (m) & $\begin{array}{c}\text { Flux } \\
\left(\mathrm{mm} \mathrm{day}^{-1}\right)\end{array}$ & WTD (m) & $\begin{array}{c}\text { Flux } \\
\left(\mathrm{mm} \mathrm{day}^{-1}\right)\end{array}$ & \\
\hline Acre & 5.59 & 3.1 & 6.49 & 2.6 & 3.99 & 3.6 & 5.07 & 3.3 & 2.0 \\
\hline Bananal Island & 2.00 & 3.7 & 2.43 & 3.1 & 1.56 & 4.0 & 1.52 & 4.0 & 3.9 \\
\hline Caxiuana & 11.44 & 1.5 & 10.71 & 1.5 & 8.44 & 2.0 & 7.95 & 2.1 & 3.6 \\
\hline Guyaflux & 10.38 & 0.8 & 8.64 & 1.1 & 6.19 & 1.5 & 8.02 & 1.2 & 4.6 \\
\hline Manaus (K34) & 14.69 & 1.8 & 13.62 & 1.9 & 11.92 & 2.1 & 11.37 & 2.2 & 3.1 \\
\hline Santarem (K67) & 8.83 & 1.2 & 9.60 & 1.0 & 6.86 & 1.5 & 5.45 & 1.9 & 2.8 \\
\hline Sinop & 11.58 & 1.1 & 13.23 & 1.0 & 9.63 & 1.2 & 8.83 & 1.3 & 2.8 \\
\hline Amazonia Mean & 9.16 & 2.1 & 9.47 & 2.2 & 7.37 & 2.6 & 7.36 & 2.6 & 3.8 \\
\hline
\end{tabular}

\section{Discussions}

The above analyses suggest that the water table is shallow in large areas in the Amazon, and that where it is shallow and the soil is fine-textured, it has the potential to support significant capillary fluxes to the land surface. However, the results presented here are based on limited observations and simple equilibrium model calculations, and as such, may have important limitations and must be interpreted accordingly. The most notable of these limitations are discussed in this section.

First, the simulated water table depth, even forced by the lowest recharge estimates (CLM), is on the average shallower than observed. This was attributed to the low bias in the observations due to wide-spread groundwater pumping (the wells are highly clustered and $98 \%$ of them are pumping wells), but it could also have been caused by a high bias in the recharge forcing (ET from water table, or negative recharge, was not considered in GLDAS models). Although CLM estimated ET (Fig. 8b) is in the right range, the nature of bias in the simulated surface runoff cannot be ascertained, and uncertainties in CLM recharge cannot be quantified. This issue can only be resolved with coupled soil water-groundwater simulations, which is our next step. In the coupled simulation, the equilibrium water table obtained here, with recharge diagnosed from off-line models, will serve as the initial water table condition, from which the system will co-evolve in response to climate forcing at multiple scales, with a fully prognostic groundwater depth.

For the purpose of the present study, the saving grace is that the simulated water table depth and the capillary flux are not highly sensitive to recharge differences. The recharge ranged 411-839 $\mathrm{m} \mathrm{yr}^{-1}$ over Amazonia among the four estimates (Fig. 3, more than doubled from CLM to HTESSEL), but the resulting mean Amazonia WTD ranged only 9.47$7.36 \mathrm{~m}$ (Fig. 5, a $1.8 \mathrm{~m}$ difference). This is because ground- water drainage is self-limiting (e.g., de Vries, 1994, 1995; Eltahir and Yeh, 1999; Marani et al., 2001); as recharge increases, the water table rises, steepening the hydraulic gradient from hills to valleys and expanding the channel network by groundwater seepage, both accelerating drainage and effectively bringing down the water table; as the recharge decreases, the water table falls, flattening the hydraulic gradient and bringing the water table below local streams, both reducing discharge and preserving the groundwater store. This negative feedback dampens the water table sensitivity to recharge uncertainties.

In addition, the $1.8 \mathrm{~m}$ difference in WTD due to the large recharge difference, only led to a range in the calculated potential capillary flux of 2.1-2.6 mm day ${ }^{-1}$ (Fig. 15, Table 4). The reason is that the main difference in WTD occurred under higher grounds, and since it is already sufficiently deep to render capillary flux insignificant, further deepening of WTD has little effect. As shown in Fig. 12b and discussed earlier, the capillary flux is sensitive to WTD only at shallow depths. Thus the uncertainties in the recharge estimates are reduced through the negative feedbacks between recharge and WTD, and the insensitivity of capillary flux to further deepening of the WTD. While acknowledging these uncertainties, we believe that they do not fundamentally alter the results presented here.

Second, the potential capillary flux is not indicative of its contribution to the actual ET, and it is only an assessment of the possible rate at which this flux can occur, or the potential power of capillary force in the soils due to a shallow water table and fine textured soils. As such, it is a theoretical result and likely much higher than what occurs in the real world of the Amazon if the top soil never dries down to the wilting point; it is well known that soil capillary flux is sensitive to the surface boundary condition (e.g., Salvucci and Entekhabi 1994, 1995; Bogaart et al., 2008). In fact, such 

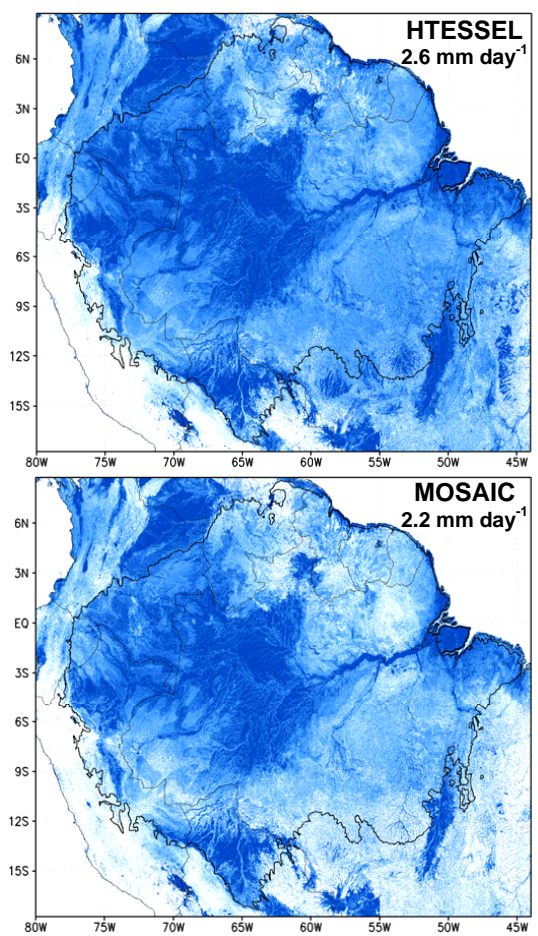
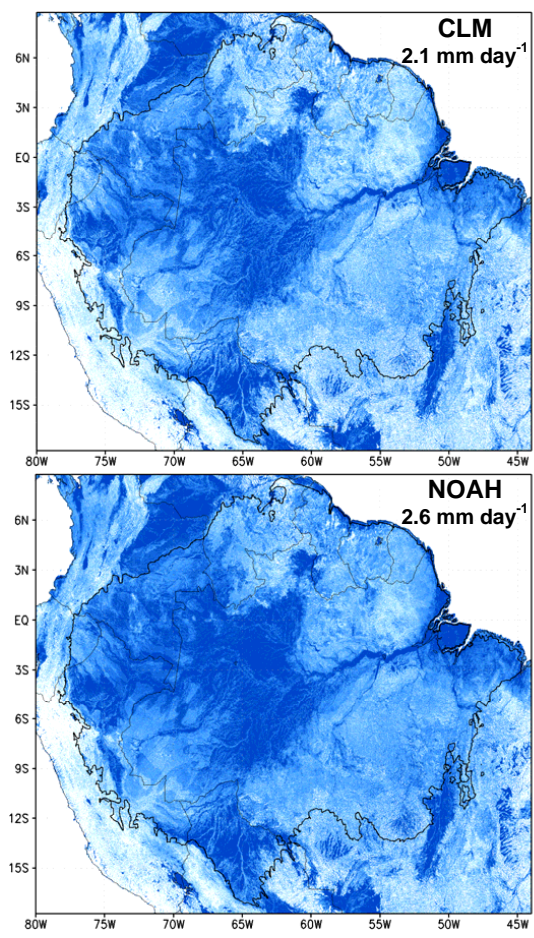

Fig. 15. Maps of potential capillary flux $\left(\mathrm{mm} \mathrm{day}^{-1}\right)$, showing Amazonian mean, based on the four WTD simulations.

dry conditions may happen only at the end of the dry season and/or in a drought; over the majority of the time and space in the Amazon, soil water flux is likely directed downward. However, the only way to assess the real and regional impact of the water table in the Amazon, with higher degrees of certainty, is through fully-coupled and dynamic model simulations which are the focus of our future work. The equilibrium water table obtained here serves as the initial state for the dynamic simulation, and together with the equilibrium potential capillary flux, will serve as a baseline to evaluate the diurnal, event, seasonal and inter-annual dynamics.

In conclusion, observations and model simulations suggest that the water table can be shallow in the lowlands and valleys in the Amazon, and that this water table distribution can potentially influence the land surface flux by supporting upward soil capillary fluxes. The actual contribution of groundwater to land surface ET can only be ascertained through coupled and dynamic simulations of soil water and groundwater feedbacks. However, similar studies conducted elsewhere have shown that inclusion of the water table in climate model simulations can increase and stabilize soil moisture and ET, cooling the surface and enhancing local convective and downwind precipitation (York et al., 2002; Liang et al., 2003; Yeh and Eltahir, 2005; Yu et al., 2006; Niu et al., 2007; Maxwell et al., 2007; Fan et al., 2007; Miguez-Macho et al., 2007; Bierkens and Van den Hurk, 2007; Maxwell and Kollet, 2008; Miguez-Macho et al., 2008; Anyah et al., 2008; Yuan et al., 2009; Jiang et al., 2009; Yeh and Famiglietti,
2009). Whether groundwater is also important in the Amazon remains to be investigated. The present study is the first step in this investigation, by establishing a climatologic equilibrium water table depth and potential (or maximum) capillary flux it can support, which will serve as the initial water table condition for the dynamic simulations and the baseline for comparison of equilibrium and dynamic results.

\section{Supplementary material related to this article is available online at: http://www.hydrol-earth-syst-sci.net/14/2039/2010/ hess-14-2039-2010-supplement.pdf.}

Acknowledgements. Support comes from the Ramón y Cajal program of the Spanish Ministry of Education and Science and Centro de Supercomputación de Galicia, CESGA at Santiago de Compostela, Galicia, Spain, the US National Science Foundation, and the Rutgers University Academic Excellence Fund. We thank the following individuals for assisting us in obtaining water table observations: Pedro Silva Dias (Universidade de Sao Paulo), Flavia Nasinmento (Brazilian Geologic Survey), Victor Donato leandro Silva (Instituto Nacional de Recursos Naturales, Peru), Luis Mosteiro Ramirez (Programa de Informacion y Documentacion Cientifica y Tecnica del CEDEX, Spain), and Lic. Daniel Cielak (Banco de Datos Hidrologico Subsecretaria de Recursos Hidricos de la Nacion, Argentina). We thank Bart van den Hurk (KNMI, the Royal Meteorological Institute of The Netherlands) for providing HTESSEL simulations and R. Simmon (NASA Earth Observatory) for the Amazonia GIS 
files. Finally we thank Ryan Teuling and Marc Bierkens for their thoughtful reviews and constructive criticisms, and we thank the editor for his conscientious handling of the paper and the thorough editing of the final draft.

Edited by: B. van den Hurk

\section{References}

Amenu, G. G. and Kumar, P.: A model for hydraulic redistribution incorporating coupled soil-root moisture transport, Hydrol. Earth Syst. Sci., 12, 55-74, doi:10.5194/hess-12-55-2008, 2008.

Anyah, R., Weaver, C. P., Miguez-Macho, G., Fan, Y., and Robock, A.: Incorporating water table dynamics in climate modeling: 3. Simulated groundwater influence on coupled land-atmosphere variability, J. Geophys. Res., 113, D07103, doi:10.1029/2007JD009087, 2008.

Baker, I. T., Prihodko, L., Denning, A. S., Goulden, M., Miller, S., and da Rocha, H. R.: Seasonal drought stress in the Amazon: Reconciling models and observations, J. Geophys. Res., 113, G00B01, doi:10.1029/2007JG000644, 2008.

Balsamo, G., Viterbo, P., Beljaars, A., van den Hurk, B., Hirschi, M., Betts, A. K., and Scipal, K.: A Revised Hydrology for the ECMWF Model: Verification from Field Site to Terrestrial Water Storage and Impact in the Integrated Forecast System, J. Hydrometeorol., 10, 623-643, doi:10.1175/2008JHM1068.1, 2009.

Bierkens, M. F. P. and Van den Hurk, B. J. J. M.: Groundwater convergence as a possible mechanism for multi-year persistence in rainfall, Geophys. Res. Lett., 34, L02402, doi:10.1029/2006GL028396, 2007.

Bogaart, P. W., Teuling, A. J., and Troch, P. A.: A state-dependent parameterization of saturated-unsaturated zone interaction, Water Resour. Res., 44, W11423, doi:10.1029/2007WR006487, 2008.

Bongers, F., Engelen, D., and Klinge, H.: Phytomass structure of natural plant communities on spodosols in southern Venezuela: the Bana woodland, Vegetatio, 63, 13-34, 1985.

Borma, L. S., da Rocha, H. R., Cabral, O. M., von Randow, C., Collicchio, E., Kuratkowski, D., Brugger, P. J., Freitas, H., Tannus, R., Oliveira, L., Renno, C. D., and Artaxo, P.: Atmosphere and hydrologic controls of the evapotranspiration over a floodplain forest in the Bananal Island region, Amazonia, J. Geophys. Res., 114, G01003, doi:10.1029/2007JG000641, 2009.

Bruno, R. D., da Rocha, H. R., de Freitas, H. C., Goulden, M. L., and Miller, S. D.: Soil moisture dynamics in an eastern Amazonian tropical forest, Hydrol. Process., 20, 2477-2489, 2006.

Burgess, S. S. O., Adams, M. A., Turner, N. C., and Ong, C. K.: The redistribution of soil water by tree root systems, Oecologia, 115, 306-311, 1998.

Caldwell, M. M., Dawson, T. E., and Richards, J. H.: Hydraulic lift: consequences of water efflux from the roots of plants, Oecologia, 113, 151-161, 1998.

Canadell, J., Jackson, R. B., Ehleringer, J. R., Mooney, H. A., Sala, O. E., and Schulze, E. D.: Maximum rooting depth of vegetation types at the global scale, Oecologia, 108, 583-595, 1996.

Clapp, R. B. and Hornberger, G. M.: Empirical equations for some soil hydraulic properties, Water Resour. Res., 14, 601-604, 1978.

Clapperton, C.: Quaternary Geology and Geomorphology of South America, Elsevier, Amsterdam, 1993.
Coomes, D. A. and Grubb, P. J.: Amazonian caatinga and related communities at La Esmeralda, Venezuela: forest structure, physiognomy and floristics, and control by soil factors, Vegetatio, 122, 167-191, 1996.

Cox P. M., Betts, R. A., Collins, M., Harris, P. P., Hungtingford, C., and Jones, C. D.: Amazonian forest dieback under climatecarbon cycle projections for the 21st century, Theor. Appl. Climatol., 78, 137-156, 2004.

Cuartas, L. A.: Estudo Observacional E De Modelagem Hidrologica De Uma Micro-Bacia Em Floresta Nao Perturbada Na Amazonia Central. Ph.D. Thesis, Instituto Nacional de Pesquisas Espaciais, Sao Jose dos Campos, available at: http://biblioteca. universia.net/html_bura/ficha/params/id/51038000.html (last access: October 2010), 2008.

Dawson, T. E.: Hydraulic lift and water use by plants: implications for water balance, performance and plant-plant interactions, Oecologia, 95, 565-574, 1993.

Delworth, T. L., Broccoli, A. J., Rosati, A., Stouffer, R. J., et al.: GFDL's CM2 Global Coupled Climate Models. Part I: Formulation And Simulation characteristics, J. Climate - Special Section, 19, 643-674, 2006.

de Vries, J. J.: Dynamics of the interface between streams and groundwater systems in lowland areas, with reference to stream net evolution, J. Hydrol., 155, 39-56, 1994.

de Vries, J. J.: Seasonal expansion and contraction of stream networks in shallow groundwater system, J. Hydrol., 170, 15-26, 1995.

Duarte A. F., de Melo W. A. F., and Brown I. F.: LBA-ECO LC02 Daily Meteorological Data, Rio Branco, Acre, Brazil: 19702001, 2008.

Eltahir, E. and Yeh, P. J.-F.: On the asymmetric response of aquifer water level to floods and droughts in Illinois, Water Resour. Res., 35, 1199-1217, 1999.

Fan, Y., Miguez-Macho, G., Weaver, C. P., Walko, R., and Robock, A.: Incorporating water table dynamics in climate modeling: 1. Water table observations and the equilibrium water table, J. Geophys. Res., 112, D10125, doi:10.1029/2006JD008111, 2007.

Fan, Y. and Miguez-Macho, G.: A simple hydrologic framework for simulating wetlands in climate and earth system models, Clim. Dynam., doi:10.1007/s00382-010-0829-8, in press, 2010.

Fisher J. A., Malhi, Y., Bonal, D., da Rocha, H. R., et al.: The land-atmosphere water flux in the tropics, Glob. Change Biol., 15, 2694-2714, 2009.

Freeze, R. A. and Cherry, J. A.: Groundwater, Prentice-Hall, New Jersey, 604 pp., 1979.

Gordon, L. J., Steffen, W., Jonsson, B. F., Folke, C., Falkenmark, M., and Johannessen, A.: Human modification of global water vapor flows from the land surface, P. Natl. Acad. Sci., 102, 76127617, 2005.

Grogan, J. and Galvao J.: Physiographic and floristic gradients across topography in transitional seasonally dry evergreen forests of southeast Para, Brazil, Acta Amazonica, 36, 483-496, 2006.

Harper, A. B., Denning, A. S., Baker, I. T., Branson, M. D., Prihodko, L., and Randall, D. A.: Role of deep soil moisture in modelating climate in the Amazon rainforest, Geophys. Res. Lett., 37, L05802, doi:10.1029/2009GL042302, 2010.

Hodnett, M. G., Vendrame, I., De O. Marques Filho, A., Oyama, M. D., and Tomasella, J.: Soil water storage and groundwater behaviour in a catenary sequence beneath forest in central Ama- 
zonia: I. Comparisons between plateau, slope and valley floor, Hydrol. Earth Syst. Sci., 1, 265-277, doi:10.5194/hess-1-2651997, 1997a.

Hodnett, M. G., Vendrame, I., De O. Marques Filho, A., Oyama, M. D., and Tomasella, J.: Soil water storage and groundwater behaviour in a catenary sequence beneath forest in central Amazonia. II. Floodplain water table behaviour and implications for streamflow generation, Hydrol. Earth Syst. Sci., 1, 279-290, doi:10.5194/hess-1-279-1997, 1997b.

Huete, A. R., Didan, K., Shimabukuro, Y. Z., Ratana, P., Saleska, S. R., Hutyra, L. R., Yang, W., Nemani, R. R., and Myneni, R.: Amazon rainforests green-up with sunlight in dry season, Geophys. Res. Lett., 33, L06405, doi:10.1029/2005GL025583, 2006.

Ichii, K., Hashimoto, H., White, M. A., Potter, C., Hutyra, L. R., Huete, A. R., Myneni, R. B., and Nemani, R. R.: Constraining rooting depths in tropical rainforests using satellite data and ecosystem modeling for accurate simulation of gross primary production seasonality, Glob. Change Biol., 13, 67-77, 2007.

Jiang, X. Y., Niu, G. Y., and Yang, Z. L.: Impacts of vegetation and groundwater dynamics on warm season precipitation over the Central United States, J. Geophys. Res., 114, D06109, doi:10.1029/2008JD010756, 2009.

Jiang, X.-W., Wan, L., Wang, X.-S., Ge, S., and Liu, J.: Effect of exponential decay in hydraulic conductivity with depth on regional groundwater flow, Geophys. Res. Lett., 34, L24402, doi:10.1029/2009GL041251, 2009.

Jirka, S., McDonald, A. J., Johnson, M. S., Feldpausch, T. R., Couto, E. G., and Riha, S. J.: Relationships between soil hydrology and forest structure and composition in the southern Brazilian Amazon, J. Veg. Sci., 18, 183-197, 2007.

Juarez, R. I. N., Hodnett, M. G., Fu, R., Goulden, M., and von Randow, C.: Control of dry season evapotranspiration over the Amazonian forest as inferred from observations at a southern Amazon forest site, J. Climate, 20, 2827-2839, 2007.

Kleidon, A. and Heimann, M.: Assessing the role of deep rooted vegetation in the climate system with model simulations: mechanism, comparison to observations and implications for Amazonian deforestation, Clim. Dynam., 16, 183-199, 2000.

Lee, J.-E. Oliveira, R. S., Dawson, T., and Fung, I.: Root functioning modifies seasonal climate, P. Natl. Acad. Sci., 102, 1757617581, 2005.

Liang, X., Xie, Z., and Huang, M.: A new parameterization for surface and ground water interactions and its impact on water budgets with the Variable Infiltration Capacity (VIC) landsurface model, J. Geophys. Res., 108(D16), 861, doi:10.1029/2002JD003090, 2003.

Loescher, H. W., Gholz, H. L., Jacobs, J. M., and Oberbauer, S. F.: Energy dynamics and modeled evapotranspiration from a wet tropical forest in Costa Rica, J. Hydrol., 315, 274-297, 2005.

Manning, C. E. and Ingebritsen, S. E.: Permeability of the continental crust: Implications of geothermal data and metamorphic systems, Rev. Geophys., 37, 127-150, 1999.

Marani, M., Eltahir, E., and Rinaldo, A.: Geomorphic controls on regional base flow, Water Resour. Res., 37, 2619-2630, 2001.

Maxwell, R. M. and Kollet, S. J.: Interdependence of groundwater dynamics and land-energy feedbacks under climate change, Nature Geosci., 1, 665-669, 2008.

Miguez-Macho, G., Fan, Y., Weaver, C. P., Walko, R., and Robock, A.: Incorporating water table dynamics in climate modeling, 2.
Formulation, validation, and simulations of soil moisture fields, J. Geophys. Res., 112, D13108, doi:10.1029/2006JD008112, 2007.

Miguez-Macho, G., Li, H., and Fan, Y.: Simulated water table and soil moisture climatology over North America, B. Am. Meteorol. Soc., 5, 663-672, 2008.

Myneni R. B., Yang, W., Nemani, R. R., Huete, A. R., Dickinson, R. E., Knyazikhin, Y., Didan, K., Fu, R., Juarez, R. I. N., Saatchi, S. S., Hashimoto, H., Ichii, K., Shabanov, N. V., Tan, B., Ratana, P., Privette, J. L., Morisette, J. T., Vermote, E. F., Roy, D. P., Wolfe, R. E., Friedl M. A., Running, S. W., Votava, P., El-Saleous, N., Devadiga, S., Su, Y., and Salomonson, V. V.: Large seasonal swings in leaf area of Amazon rainforests, P. Natl. Acad. Sci., 104, 4820-4823, 2007.

Nepstad D. C., de Carvalho, C. R., Davidson, E. A., Jipp, P. H., Lefebvre, P. A., Negreiros, G. H., da Silva, E. D., Stone, T. A., Trumbore, S. E., and Vieira, S.: The role of deep roots in the hydrological and carbon cycles of Amazonian forests and pastures, Nature, 372, 666-669, 1994.

Nepstad D. C., Moutinho, P., Dias-Filho, M. B., Davidson, E., Gardinot, G., Markewitz, D., Figueiredo, R., Vianna, N., Chambers, J., Ray, D., Guerreiros, J. B., Lefebvre, P., Sternberg, L., Moreira, M., Barrons, L., Ishida, F. Y., Tohlver, I., Belk, E., Kalif, K., and Schwalbe, K.: The effects of partial throughfall exclusion on canopy processes, aboveground production, and biogeochemistry of an Amazon forest, J. Geophys. Res., 107(D20), 8080, doi:10.1029/2001JD000360, 2002.

Niu, G. Y., Yang, Z. L., Dickinson, R. E., Gulden, L. E., and Su, H.: Development of a simple groundwater model for use in climate models and evaluation with GRACE data, J. Geophys. Res., 112(D7), D07103, doi:10.1029/2006JD007522, 2007.

Oliveira, R. S., Dawson, T. E., Burgess, S. S. O., and Nepstad, D. C.: Hydraulic redistribution in three Amazonian trees, Oecologia, 145, 354-363, 2005.

Poels, R. L. H.: Soils, Water and Nutrients in a Forest Ecosystem in Suriname, Agr. Univ., Wageningen, The Netherlands, 1987.

da Rocha, H. R., Manzi, A. O., Cabral, O. M., Miller, S. D., Goulden, M. L., Saleska, S. R., Coupe N. R., Wofsy, S. C., Borma, L. S., Artaxo, P., Vourlitis, G., Nogueira, J. S., Cardoso, F. L., Nobre, A. D., Kruijt, B., Freitas, H. C., von Randow, C., Aguiar, R. G., and Maia, J. F.: Patterns of water and heat flux across a biome gradient from tropical forest to savanna in Brazil. J. Geophys. Res., 114, G00B12, doi:10.1029/2007JG000640, 2009.

Rodell, M., Houser, P. R., Jambor, U., Gottschalck, J., Mitchell, K., Meng, C. -J., Arsenault, K., Cosgrove, B., Radakovich, J., Bosilovich, M., Entin, J. K., Walker, J. P., Lohmann, D., and Toll, D.: The global land data assimilation system, B. Am. Meteorol. Soc., 85, 381-394, 2004.

Romero-Saltos, H. L., Sternberg, L. da S. L., Moreira, M. Z., and Nepstad, D. C.: Rainfall exclusion in an eastern Amazonian forest alters soil water movement and depth to water uptake, Am. J. Botany, 92, 443-455, 2005.

Saleska, S. R., Miller, S. D., Matross, D. M., Goulden, M. L., Wofsy, S. C., da Rocha, H. R., de Camargo, P. B., Crill, P., Daube, B. C., de Freitas, H. C., Hutyra, L., Keller, M., Kirchhoff, V., Menton, M., Munger, J. W., Pyle, E. H., Rice, A. H., and Silva, H.: Carbon in Amazon Forests: Unexpected seasonal fluxes and disturbance-induced losses, Science, 302, 1554-1557, 
2003.

Salvucci, G. D. and Entekhabi, D.: Equivalent steady moisture profile and time compression approximation in water balance modeling, Water Resour. Res., 30, 2751-2757, 1994.

Salvucci, G. D. and Entekhabi, D.: Ponded infiltration into soils bounded by a water table, Water Resour. Res., 31, 2751-2759, 1995.

Selhorst, D., Vieira, S. A., and Brown, I. F.: Água e crescimento de uma floresta na Amazônia Sul-Ocidental, Acre, Brasil: chuva afeta crescimento, mas nível do lençol freático não, Poster presentation, available at: ftp://lba.cptec.inpe.br/lba_archives/ LC/LC-02/Posters/SelhorstDiogo_Poster_VI_CEB_02nov03.pdf (last access: October 2010), 2003.

Schenck, H. J. and Jackson, R. B.: The global biogeography of roots, Ecologic Monographs, 72, 311-328, 2002.

Shuttleworth, W. J.: Evaporation from Amazonian rainforest, Proceedings of the Royal Society of London, B233, 321-346, 1988.

Sternberg, L. da S. L., Moreira, M. Z., and Nepstad, D. C.: Uptake of water by lateral roots of small trees in an Amazonian tropical forest, Plant Soil, 238, 151-158, 2002.

Tomasella, J., Hodnett, M. G., Cuartas, L. A., Nobre, A. D., Waterloo, M. J., and Oliveira, S. M.: The water balance of an Amazonian micro-catchment: the effect of interannual variability of rainfall on hydrological behavior, Hydrol. Process., 22, 21332147, 2008.

Vourlitis, G. L., Nogueira, J. D., Lobo, F. D., Sendall, K. M., de Paulo, S. R., Dias, C. A. A., Pinto Jr., O. B., and de Andrade, N. L. R.: Energy balance and canopy conductance of a tropical semi-deciduous forest of the southern Amazon Basin, Water Resour. Res., 44, W03412, doi:10.1029/2006WR005526, 2008.
Wallace, A. R.: A Narrative of Travels on the Amazon and Rio Negro, Ward, Lock and Co., London, 1889.

Werth, D. and Avissar, R.: The regional evapotranspiration of the Amazon, J. Hydrometeorol., 5, 100-109, 2004.

Whitmore, T. C. and Prance, G. T.: Biogeography and Quaternary History in Tropical America, Clarendon Press, Oxford, 1987.

Xiao, X., Zhang, Q., Saleska, S., Hutyra, L., De Camargo, P., Wofsy, S., Frolking, S., Boles, S., Keller, M., and Moore, B.: Satellite-based modeling of gross primary production in a seasonally moist tropical evergreen forest, Remote Sens. Environ., 94, 105-122, 2005.

Yeh, P. J. F. and Eltahir, E. A. B.: Representation of water table dynamics in a landsurface scheme, Part I: Model development, J. Climate, 18, 1861-1880, 2005.

Yeh, P. J. F. and Famiglietti, J. S.: Regional groundwater evaporation in Illinois, J. Hydrometeorol., 10, 464-478, doi:10.1175/2008JHM1018.1, 2009.

York, J. P., Person, M., Gutowski, W. J., and Winter, T. C.: Putting aquifers into atmospheric simulation models: An example from Mill Creek Watershed, northeastern Kansas, Adv. Water Res., 25, 221-238, 2002.

Yu, Z., Pollard, D., and Cheng, L.: On continental-scale hydrologic simulations with a coupled hydrologic model, J. Hydrol., 331, 110-124, 2006.

Yuan, X., Xie Z. H., Zheng, J., Tian, X. J., and Yang, Z. L.: Effects of water table dynamics on regional climate: A case study over east Asian monsoon area, J. Geophys. Res., 113(D21), D21112, doi:10.1029/2008JD010180, 2008. 